\title{
5-Hydroxytryptamine receptors (version 2019.4) in the IUPHAR/BPS Guide to Pharmacology Database
}

Rodrigo Andrade ${ }^{1}$, Nicholas M. Barnes ${ }^{2}$, Gordon Baxter ${ }^{3}$, Joel Bockaert ${ }^{1}$, Theresa Branchek ${ }^{4}$, Amy Butler Marlene L. Cohen ${ }^{5}$, Aline Dumuis ${ }^{6}$, Richard M. Eglen ${ }^{7}$, Manfred Göthert ${ }^{8}$, Mark Hamblin ${ }^{9}$, Michel Hamon ${ }^{10}$, Paul R. Hartig ${ }^{11}$, René Hen ${ }^{12}$, Julie Hensler ${ }^{13}$, Katharine Herrick-Davis ${ }^{14}$, Rebecca Hills ${ }^{15}$, Daniel Hoyer ${ }^{16}$, Patrick P. A. Humphrey ${ }^{17}$, Klaus Peter Latté ${ }^{18}$, Luc Maroteaux ${ }^{19}$, Graeme R. Martin ${ }^{20}$, Derek N. Middlemiss ${ }^{21}$, Ewan Mylecharane ${ }^{22}$, John Neumaier ${ }^{23}$, Stephen J. Peroutka ${ }^{24}$, John A. Peters ${ }^{25}$, Bryan Roth ${ }^{26}$, Pramod R. Saxena ${ }^{27}$, Trevor Sharp ${ }^{28}$, Andrew Sleight ${ }^{29}$, Carlos M. Villalon ${ }^{30}$ and Frank Yocca ${ }^{31}$

1. Wayne State University, USA

2. University of Birmingham, UK

3. Pharmagene Laboratories, UK

4. Synaptic Pharmaceutical Corporation, USA

5. Lilly Research Laboratories, USA

6. Université de Montpellier, France

7. PerkinEImer, UK

8. Universität Bonn, Germany

9. Puget Sound Geriatric Research Education and Clinical Center, USA

10. Sorbonne Université, France

11. DuPont-Merck Pharmaceutical Company, USA

12. Columbia University, USA

13. University of Texas, USA

14. Albany Medical College, USA

15. University of Edinburgh, UK

16. University of Melbourne, Australia

17. University of Cambridge, UK

18. Axxonis Pharma AG, Germany

19. Sorbonne University, France

20. Discovery-Insight, USA

21. GlaxoSmithKline, UK

22. University of Sydney, Australia

23. University of Washington, USA

24. PPD Pharmaceuticals, USA

25. University of Dundee, UK

26. University of North Carolina, USA

27. Erasmus Universiteit Rotterdam, The Netherlands

28. University of Oxford, UK

29. Hoffman-La Roche, Switzerland

30. Cinvestav, Mexico

31. Bristol-Myers Squibb, USA 


\begin{abstract}
5-HT receptors (nomenclature as agreed by the NC-IUPHAR Subcommittee on 5-HT receptors [194] and subsequently revised [176]) are, with the exception of the ionotropic $5-\mathrm{H}_{3}$ class, GPCRs where the endogenous agonist is 5 -hydroxytryptamine. The diversity of metabotropic $5-\mathrm{HT}$ receptors is increased by alternative splicing that produces isoforms of the $5-\mathrm{HT}_{2 \mathrm{~A}}$ (non-functional), $5-\mathrm{HT}_{2 \mathrm{C}}$ (non-functional), $5-\mathrm{HT}_{4}, 5-\mathrm{HT}_{6}$ (non-functional) and $5-\mathrm{HT}_{7}$ receptors. Unique amongst the GPCRs, RNA editing produces $5-\mathrm{HT}_{2} \mathrm{C}$ receptor isoforms that differ in function, such as efficiency and specificity of coupling to $G_{q / 11}$ and also pharmacology [40, 482]. Most $5-\mathrm{HT}$ receptors (except 5 -ht $_{1_{e}}$ and 5 -ht $t_{5 b}$ ) play specific roles mediating functional responses in different tissues (reviewed by [463, 382]).
\end{abstract}

\title{
Contents
}

This is a citation summary for 5-Hydroxytryptamine receptors in the Guide to Pharmacology database (GtoPdb). It exists purely as an adjunct to the database to facilitate the recognition of citations to and from the database by citation analyzers. Readers will almost certainly want to visit the relevant sections of the database which are given here under database links.

GtoPdb is an expert-driven guide to pharmacological targets and the substances that act on them. GtoPdb is a reference work which is most usefully represented as an on-line database. As in any publication this work should be appropriately cited, and the papers it cites should also be recognized. This document provides a citation for the relevant parts of the database, and also provides a reference list for the research cited by those parts.

Please note that the database version for the citations given in GtoPdb are to the most recent preceding version in which the family or its subfamilies and targets were substantially changed. The links below are to the current version. If you need to consult the cited version, rather than the most recent version, please contact the GtoPdb curators.

\section{Database links}

\section{5-Hydroxytryptamine receptors}

http://www.guidetopharmacology.org/GRAC/FamilyDisplayForward?familyld=1

Introduction to 5-Hydroxytryptamine receptors

http://www.guidetopharmacology.org/GRAC/FamilyIntroductionForward?familyld=1

Receptors

5- $\mathrm{HT}_{1 \mathrm{~A}}$ receptor

http://www.guidetopharmacology.org/GRAC/ObjectDisplayForward?objectld=1

5- $\mathrm{HT}_{1 \mathrm{~B}}$ receptor

http://www.guidetopharmacology.org/GRAC/ObjectDisplayForward?objectld=2

5- $\mathrm{HT}_{1 \mathrm{D}}$ receptor

http://www.guidetopharmacology.org/GRAC/ObjectDisplayForward?objectld=3

$5-\mathrm{ht}_{1 \mathrm{e}}$ receptor

http://www.guidetopharmacology.org/GRAC/ObjectDisplayForward?objectld=4

5- $\mathrm{HT}_{1 \mathrm{~F}}$ receptor

http://www.guidetopharmacology.org/GRAC/ObjectDisplayForward?objectld=5

5- $\mathrm{HT}_{2 \mathrm{~A}}$ receptor

http://www.guidetopharmacology.org/GRAC/ObjectDisplayForward?objectld=6

5- $\mathrm{HT}_{2 \mathrm{~B}}$ receptor

http://www.guidetopharmacology.org/GRAC/ObjectDisplayForward?objectld=7 
$5-\mathrm{HT}_{2 \mathrm{C}}$ receptor

http://www.guidetopharmacology.org/GRAC/ObjectDisplayForward?objectld=8

$5-\mathrm{HT}_{4}$ receptor

http://www.guidetopharmacology.org/GRAC/ObjectDisplayForward?objectld=9

5- $\mathrm{HT}_{5 \mathrm{~A}}$ receptor

http://www.guidetopharmacology.org/GRAC/ObjectDisplayForward?objectld=10

$5-\mathrm{ht}_{5 \mathrm{~b}}$ receptor

http://www.guidetopharmacology.org/GRAC/ObjectDisplayForward?objectld=648

$5-\mathrm{HT}_{6}$ receptor

http://www.guidetopharmacology.org/GRAC/ObjectDisplayForward?objectld=11

$5-\mathrm{HT}_{7}$ receptor

http://www.guidetopharmacology.org/GRAC/ObjectDisplayForward?objectld=12

\section{References}

1. Adham N, Bard JA, Zgombick JM, Durkin MM, Kucharewicz S, Weinshank RL and Branchek TA. (1997) Cloning and characterization of the guinea pig 5-HT1F receptor subtype: a comparison of the pharmacological profile to the human species homolog. Neuropharmacology 36: 569-76 [PMID:9225282]

2. Adham N, Borden LA, Schechter LE, Gustafson EL, Cochran TL, Vaysse PJ, Weinshank RL and Branchek TA. (1993) Cell-specific coupling of the cloned human 5-HT1F receptor to multiple signal transduction pathways. Naunyn Schmiedebergs Arch. Pharmacol. 348: 566-75 [PMID:8133900]

3. Adham N, Gerald C, Schechter L, Vaysse P, Weinshank R and Branchek T. (1996) [3H]5hydroxytryptamine labels the agonist high affinity state of the cloned rat 5-HT4 receptor. Eur. J. Pharmacol. 304: 231-5 [PMID:8813606]

4. Adham N, Kao HT, Schecter LE, Bard J, Olsen M, Urquhart D, Durkin M, Hartig PR, Weinshank RL and Branchek TA. (1993) Cloning of another human serotonin receptor (5-HT1F): a fifth 5-HT1 receptor subtype coupled to the inhibition of adenylate cyclase. Proc. Natl. Acad. Sci. U.S.A. 90: 408-12 [PMID:8380639]

5. Adham N, Romanienko P, Hartig P, Weinshank RL and Branchek T. (1992) The rat 5hydroxytryptamine1B receptor is the species homologue of the human 5-hydroxytryptamine1D beta receptor. Mol. Pharmacol. 41: 1-7 [PMID:1732716]

6. Adham N, Vaysse PJ, Weinshank RL and Branchek TA. (1994) The cloned human 5-HT1E receptor couples to inhibition and activation of adenylyl cyclase via two distinct pathways in transfected BS-C-1 cells. Neuropharmacology 33: 403-10 [PMID:7984278]

7. Adham N, Zgombick JM, Bard J and Branchek TA. (1998) Functional characterization of the recombinant human 5-hydroxytryptamine7(a) receptor isoform coupled to adenylate cyclase stimulation. J. Pharmacol. Exp. Ther. 287: 508-14 [PMID:9808674]

8. Ahern GP. (2011) 5-HT and the immune system. Curr Opin Pharmacol 11: 29-33 [PMID:21393060]

9. Albert PR, Sajedi N, Lemonde S and Ghahremani MH. (1999) Constitutive G(i2)-dependent activation of adenylyl cyclase type II by the 5-HT1A receptor. Inhibition by anxiolytic partial agonists. J. Biol. Chem. 274: 35469-74 [PMID:10585418]

10. Albert PR, Zhou QY, Van Tol HH, Bunzow JR and Civelli O. (1990) Cloning, functional expression, and mRNA tissue distribution of the rat 5-hydroxytryptamine1A receptor gene. J. Biol. Chem. 265: 5825-32 [PMID:2156831]

11. Almaula N, Ebersole BJ, Zhang D, Weinstein H and Sealfon SC. (1996) Mapping the binding site pocket of the serotonin 5-Hydroxytryptamine2A receptor. Ser3.36(159) provides a second interaction site for the protonated amine of serotonin but not of lysergic acid diethylamide or bufotenin. J. Biol. Chem. 271: 14672-5 [PMID:8663249]

12. Amlaiky N, Ramboz S, Boschert U, Plassat JL and Hen R. (1992) Isolation of a mouse "5HT1E-like" serotonin receptor expressed predominantly in hippocampus. J. Biol. Chem. 267: 19761-4 [PMID:1328180] 
13. Asakawa A, Ueno N, Katagi M, ljuin Y, Morita Y, Mizuno S, Inui T, Sakamaki R, Shinfuku N and Uemoto M. (2006) Mosapride improves food intake, while not worsening glycemic control and obesity, in ob/ob obese mice with decreased gastric emptying. J. Diabetes Complicat. 20: 56-8 [PMID:16389169]

14. Ase AR, Reader TA, Hen R, Riad M and Descarries L. (2000) Altered serotonin and dopamine metabolism in the CNS of serotonin 5-HT(1A) or 5-HT(1B) receptor knockout mice. J. Neurochem. 75: 2415-26 [PMID:11080193]

15. Ase AR, Reader TA, Hen R, Riad M and Descarries L. (2001) Regional changes in density of serotonin transporter in the brain of 5-HT1A and 5-HT1B knockout mice, and of serotonin innervation in the 5-HT1B knockout. J. Neurochem. 78: 619-30 [PMID:11483665]

16. Ayme-Dietrich E, Lawson R, Côté F, de Tapia C, Da Silva S, Ebel C, Hechler B, Gachet C, Guyonnet J and Rouillard $\mathrm{H}$ et al.. (2017) The role of $5-\mathrm{HT}_{2 \mathrm{~B}}$ receptors in mitral valvulopathy: bone marrow mobilization of endothelial progenitors. Br. J. Pharmacol. 174: 4123-4139 [PMID:28806488]

17. Aznar S, Qian Z, Shah R, Rahbek B and Knudsen GM. (2003) The 5-HT1A serotonin receptor is located on calbindin- and parvalbumin-containing neurons in the rat brain. Brain Res. 959: 58-67 [PMID:12480158]

18. Bach T, Syversveen T, Kvingedal AM, Krobert KA, Brattelid T, Kaumann AJ and Levy FO. (2001) 5HT4(a) and 5-HT4(b) receptors have nearly identical pharmacology and are both expressed in human atrium and ventricle. Naunyn Schmiedebergs Arch. Pharmacol. 363: 146-60 [PMID:11218067]

19. Bagdy G, Graf M, Anheuer ZE, Modos EA and Kantor S. (2001) Anxiety-like effects induced by acute fluoxetine, sertraline or m-CPP treatment are reversed by pretreatment with the 5-HT2C receptor antagonist SB-242084 but not the 5-HT1A receptor antagonist WAY-100635. Int. J. Neuropsychopharmacol. 4: 399-408 [PMID:11806866]

20. Bai F, Yin T, Johnstone EM, Su C, Varga G, Little SP and Nelson DL. (2004) Molecular cloning and pharmacological characterization of the guinea pig 5-HT1E receptor. Eur. J. Pharmacol. 484: 127-39 [PMID:14744596]

21. Baker LP, Nielsen MD, Impey S, Metcalf MA, Poser SW, Chan G, Obrietan K, Hamblin MW and Storm DR. (1998) Stimulation of type 1 and type $8 \mathrm{Ca2}+/$ calmodulin-sensitive adenylyl cyclases by the Gscoupled 5-hydroxytryptamine subtype 5-HT7A receptor. J. Biol. Chem. 273: 17469-76 [PMID:9651336]

22. Banasr M, Hery M, Printemps R and Daszuta A. (2004) Serotonin-induced increases in adult cell proliferation and neurogenesis are mediated through different and common $5-\mathrm{HT}$ receptor subtypes in the dentate gyrus and the subventricular zone. Neuropsychopharmacology 29: 450-60 [PMID:14872203]

23. Banes A, Florian JA and Watts SW. (1999) Mechanisms of 5-hydroxytryptamine(2A) receptor activation of the mitogen-activated protein kinase pathway in vascular smooth muscle. J. Pharmacol. Exp. Ther. 291: 1179-87 [PMID:10565840]

24. Bang-Andersen B, Ruhland T, Jørgensen M, Smith G, Frederiksen K, Jensen KG, Zhong H, Nielsen SM, Hogg S and Mørk A et al.. (2011) Discovery of 1-[2-(2,4-dimethylphenylsulfanyl)phenyl]piperazine (Lu AA21004): a novel multimodal compound for the treatment of major depressive disorder. J. Med. Chem. 54: 3206-21 [PMID:21486038]

25. Bard JA, Zgombick J, Adham N, Vaysse P, Branchek TA and Weinshank RL. (1993) Cloning of a novel human serotonin receptor (5-HT7) positively linked to adenylate cyclase. J. Biol. Chem. 268: 23422-6 [PMID:8226867]

26. Bartsch T, Knight YE and Goadsby PJ. (2004) Activation of 5-HT(1B/1D) receptor in the periaqueductal gray inhibits nociception. Ann. Neurol. 56: 371-81 [PMID:15349864]

27. Baxter GS, Craig DA and Clarke DE. (1991) 5-Hydroxytryptamine4 receptors mediate relaxation of the rat oesophageal tunica muscularis mucosae. Naunyn Schmiedebergs Arch. Pharmacol. 343: 439-46 [PMID:1881455]

28. Beattie DT, Smith JA, Marquess D, Vickery RG, Armstrong SR, Pulido-Rios T, McCullough JL, Sandlund C, Richardson C and Mai N et al.. (2004) The 5-HT4 receptor agonist, tegaserod, is a potent 5-HT2B receptor antagonist in vitro and in vivo. Br. J. Pharmacol. 143: 549-60 [PMID:15466450]

29. Belenky MA and Pickard GE. (2001) Subcellular distribution of 5-HT(1B) and 5-HT(7) receptors in the mouse suprachiasmatic nucleus. J. Comp. Neurol. 432: 371-88 [PMID:11246214] 
30. Bender E, Pindon A, van Oers I, Zhang YB, Gommeren W, Verhasselt P, Jurzak M, Leysen J and Luyten W. (2000) Structure of the human serotonin 5-HT4 receptor gene and cloning of a novel 5-HT4 splice variant. J. Neurochem. 74: 478-89 [PMID:10646498]

31. Bentley JC, Bourson A, Boess FG, Fone KC, Marsden CA, Petit N and Sleight AJ. (1999) Investigation of stretching behaviour induced by the selective 5-HT6 receptor antagonist, Ro 04-6790, in rats. Br. J. Pharmacol. 126: 1537-42 [PMID:10323584]

32. Berg KA, Cropper JD, Niswender CM, Sanders-Bush E, Emeson RB and Clarke WP. (2001) RNA-editing of the 5-HT(2C) receptor alters agonist-receptor-effector coupling specificity. Br. J. Pharmacol. 134: 386-92 [PMID:11564657]

33. Bergen AW, van den Bree MB, Yeager M, Welch R, Ganjei JK, Haque K, Bacanu S, Berrettini WH, Grice DE and Goldman D et al.. (2003) Candidate genes for anorexia nervosa in the 1p33-36 linkage region: serotonin 1D and delta opioid receptor loci exhibit significant association to anorexia nervosa. Mol. Psychiatry 8: 397-406 [PMID:12740597]

34. Bernotas RC, Lenicek S, Antane S, Cole DC, Harrison BL, Robichaud AJ, Zhang GM, Smith D, Platt B and Lin $Q$ et al.. (2009) Novel 1-aminoethyl-3-arylsulfonyl-1H-pyrrolo[2,3-b]pyridines are potent 5-HT(6) agonists. Bioorg. Med. Chem. 17: 5153-63 [PMID:19523834]

35. Berque-Bestel I, Soulier JL, Giner M, Rivail L, Langlois M and Sicsic S. (2003) Synthesis and characterization of the first fluorescent antagonists for human 5-HT4 receptors. J. Med. Chem. 46: 2606-20 [PMID:12801225]

36. Bert B, Dere E, Wilhelmi N, Kusserow H, Theuring F, Huston JP and Fink H. (2005) Transient overexpression of the $5-\mathrm{HT} 1 \mathrm{~A}$ receptor impairs water-maze but not hole-board performance. Neurobiol Learn Mem 84: 57-68 [PMID:15936683]

37. Blair JB, Kurrasch-Orbaugh D, Marona-Lewicka D, Cumbay MG, Watts VJ, Barker EL and Nichols DE. (2000) Effect of ring fluorination on the pharmacology of hallucinogenic tryptamines. J. Med. Chem. 43: 4701-10 [PMID:11101361]

38. Blondel O, Gastineau M, Dahmoune Y, Langlois M and Fischmeister R. (1998) Cloning, expression, and pharmacology of four human 5-hydroxytryptamine 4 receptor isoforms produced by alternative splicing in the carboxyl terminus. J. Neurochem. 70: 2252-61 [PMID:9603189]

39. Blondel O, Vandecasteele G, Gastineau M, Leclerc S, Dahmoune Y, Langlois M and Fischmeister R. (1997) Molecular and functional characterization of a 5-HT4 receptor cloned from human atrium. FEBS Lett. 412: 465-74 [PMID:9276448]

40. Bockaert J, Claeysen S, Bécamel C, Dumuis A and Marin P. (2006) Neuronal 5-HT metabotropic receptors: fine-tuning of their structure, signaling, and roles in synaptic modulation. Cell Tissue Res. 326: 553-72 [PMID:16896947]

41. Bockaert J, Claeysen S, Compan V and Dumuis A. (2004) 5-HT4 receptors.Curr Drug Targets CNS Neurol Disord 3: 39-51 [PMID:14965243]

42. Bockaert J, Sebben M and Dumuis A. (1990) Pharmacological characterization of 5-hydroxytryptamine4(5HT4) receptors positively coupled to adenylate cyclase in adult guinea pig hippocampal membranes: effect of substituted benzamide derivatives. Mol. Pharmacol. 37: 408-11 [PMID:2314390]

43. Boddeke HW, Hoffman BJ, Palacios JM, Knot H and Hoyer D. (1993) Characterization of functional responses in A9 cells transfected with cloned rat 5-HT1C receptors. Naunyn Schmiedebergs Arch. Pharmacol. 347: 119-24 [PMID:8474532]

44. Boehme SA, Lio FM, Sikora L, Pandit TS, Lavrador K, Rao SP and Sriramarao P. (2004) Cutting edge: serotonin is a chemotactic factor for eosinophils and functions additively with eotaxin. J. Immunol. 173: 3599-603 [PMID:15356103]

45. Boess FG, Monsma FJ, Meyer V, Zwingelstein C and Sleight AJ. (1997) Interaction of tryptamine and ergoline compounds with threonine 196 in the ligand binding site of the 5-hydroxytryptamine6 receptor. Mol Pharmacol 52: 515-523 [PMID:9284367]

46. Boess FG, Monsma Jr FJ, Carolo C, Meyer V, Rudler A, Zwingelstein C and Sleight AJ. (1997) Functional and radioligand binding characterization of rat 5-HT6 receptors stably expressed in HEK293 cells. 
Neuropharmacology 36: 713-20 [PMID:9225298]

47. Boess FG, Monsma Jr FJ and Sleight AJ. (1998) Identification of residues in transmembrane regions III and $\mathrm{VI}$ that contribute to the ligand binding site of the serotonin 5-HT6 receptor. J. Neurochem. 71: 216977 [PMID:9798944]

48. Boess FG, Riemer C, Bos M, Bentley J, Bourson A and Sleight AJ. (1998) The 5-hydroxytryptamine6 receptor-selective radioligand [3H]Ro 63-0563 labels 5-hydroxytryptamine receptor binding sites in rat and porcine striatum. Mol Pharmacol 54: 577-583 [PMID:9730917]

49. Bonaventure P, Dugovic C, Kramer M, De Boer P, Singh J, Wilson S, Bertelsen K, Di J, Shelton J and Aluisio L et al.. (2012) Translational evaluation of JNJ-18038683, a 5-hydroxytryptamine type 7 receptor antagonist, on rapid eye movement sleep and in major depressive disorder. J. Pharmacol. Exp. Ther. 342: 429-40 [PMID:22570363]

50. Bonaventure P, Hall H, Gommeren W, Cras P, Langlois X, Jurzak M and Leysen JE. (2000) Mapping of serotonin 5-HT(4) receptor mRNA and ligand binding sites in the post-mortem human brain. Synapse 36: 35-46 [PMID:10700024]

51. Bonaventure P, Schotte A, Cras P and Leysen JE. (1997) Autoradiographic mapping of 5-HT1B- and 5$\mathrm{HT} 1 \mathrm{D}$ receptors in human brain using [3H]alniditan, a new radioligand. Recept. Channels 5: 225-30 [PMID:9606727]

52. Bonhaus DW, Berger J, Adham N, Branchek TA, Hsu SA, Loury DN, Leung E, Wong EH, Clark RD and Eglen RM. (1997) [3H]RS 57639, a high affinity, selective 5-HT4 receptor partial agonist, specifically labels guinea-pig striatal and rat cloned (5-HT4S and 5-HT4L) receptors. Neuropharmacology 36: 671-9 [PMID:9225293]

53. Bonhaus DW, Flippin LA, Greenhouse RJ, Jaime S, Rocha C, Dawson M, Van Natta K, Chang LK, PulidoRios T and Webber A et al.. (1999) RS-127445: a selective, high affinity, orally bioavailable 5-HT2B receptor antagonist. Br. J. Pharmacol. 127: 1075-82 [PMID:10455251]

54. Bonhaus DW, Weinhardt KK, Taylor M, DeSouza A, McNeeley PM, Szczepanski K, Fontana DJ, Trinh J, Rocha CL and Dawson MW et al.. (1997) RS-102221: a novel high affinity and selective, 5-HT2C receptor antagonist. Neuropharmacology 36: 621-9 [PMID:9225287]

55. Borsini F, Evans K, Jason K, Rohde F, Alexander B and Pollentier S. (2002) Pharmacology of flibanserin. CNS Drug Rev 8: 117-42 [PMID:12177684]

56. Bortolozzi A, Amargós-Bosch M, Toth M, Artigas F and Adell A. (2004) In vivo efflux of serotonin in the dorsal raphe nucleus of 5-HT1A receptor knockout mice. J. Neurochem. 88: 1373-9 [PMID:15009637]

57. Boulenguez P, Segu L, Chauveau J, Morel A, Lanoir J and Delaage M. (1992) Biochemical and pharmacological characterization of serotonin-O-carboxymethylglycyl[125I]iodotyrosinamide, a new radioiodinated probe for 5-HT1B and 5-HT1D binding sites. J. Neurochem. 58: 951-9 [PMID:1738002]

58. Bourson A, Boess FG, Bös M and Sleight AJ. (1998) Involvement of 5-HT6 receptors in nigro-striatal function in rodents. Br. J. Pharmacol. 125: 1562-6 [PMID:9884085]

59. Bourson A, Borroni E, Austin RH, Monsma Jr FJ and Sleight AJ. (1995) Determination of the role of the 5ht6 receptor in the rat brain: a study using antisense oligonucleotides. J. Pharmacol. Exp. Ther. 274: 17380 [PMID:7616396]

60. Boutrel B, Monaca C, Hen R, Hamon M and Adrien J. (2002) Involvement of 5-HT1A receptors in homeostatic and stress-induced adaptive regulations of paradoxical sleep: studies in 5-HT1A knock-out mice. J. Neurosci. 22: 4686-92 [PMID:12040075]

61. Branchek T, Adham N, Macchi M, Kao HT and Hartig PR. (1990) [3H]-DOB(4-bromo-2,5dimethoxyphenylisopropylamine) and $[3 \mathrm{H}]$ ketanserin label two affinity states of the cloned human 5 hydroxytryptamine2 receptor. Mol. Pharmacol. 38: 604-9 [PMID:2233697]

62. Brattelid T, Kvingedal AM, Krobert KA, Andressen KW, Bach T, Hystad ME, Kaumann AJ and Levy FO. (2004) Cloning, pharmacological characterisation and tissue distribution of a novel 5-HT4 receptor splice variant, 5-HT4(i). Naunyn Schmiedebergs Arch. Pharmacol. 369: 616-28 [PMID:15118808]

63. Brenchat A, Romero L, García M, Pujol M, Burgueño J, Torrens A, Hamon M, Baeyens JM, Buschmann H and Zamanillo $D$ et al.. (2009) 5-HT7 receptor activation inhibits mechanical hypersensitivity secondary to 
capsaicin sensitization in mice. Pain 141: 239-47 [PMID:19118950]

64. Brennan TJ, Seeley WW, Kilgard M, Schreiner CE and Tecott LH. (1997) Sound-induced seizures in serotonin 5-HT2C receptor mutant mice. Nat. Genet. 16: 387-90 [PMID:9241279]

65. Briejer MR, Bosmans JP, Van Daele P, Jurzak M, Heylen L, Leysen JE, Prins NH and Schuurkes JA. (2001) The in vitro pharmacological profile of prucalopride, a novel enterokinetic compound. Eur. J. Pharmacol. 423: 71-83 [PMID:11438309]

66. Brodney MA, Johnson DE, Sawant-Basak A, Coffman KJ, Drummond EM, Hudson EL, Fisher KE, Noguchi $\mathrm{H}$, Waizumi $\mathrm{N}$ and McDowell LL et al.. (2012) Identification of multiple 5- $\mathrm{HT}_{4}$ partial agonist clinical candidates for the treatment of Alzheimer's disease. J. Med. Chem. 55: 9240-54 [PMID:22974325]

67. Bromidge SM, Brown AM, Clarke SE, Dodgson K, Gager T, Grassam HL, Jeffrey PM, Joiner GF, King FD and Middlemiss DN et al.. (1999) 5-Chloro-N-(4-methoxy-3-piperazin-1-yl- phenyl)-3-methyl-2benzothiophenesulfon- amide (SB-271046): a potent, selective, and orally bioavailable 5-HT6 receptor antagonist. J. Med. Chem. 42: 202-5 [PMID:9925723]

68. Bromidge SM, Clarke SE, Gager T, Griffith K, Jeffrey P, Jennings AJ, Joiner GF, King FD, Lovell PJ and Moss SF et al.. (2001) Phenyl benzenesulfonamides are novel and selective 5-HT6 antagonists: identification of $\mathrm{N}$-(2,5-dibromo-3-fluorophenyl)-4-methoxy-3-piperazin-1-ylbenzenesulfonamide (SB357134). Bioorg. Med. Chem. Lett. 11: 55-8 [PMID:11140733]

69. Bromidge SM, Dabbs S, Davies DT, Davies S, Duckworth DM, Forbes IT, Gaster LM, Ham P, Jones GE and King FD et al.. (2000) Biarylcarbamoylindolines are novel and selective 5-HT(2C) receptor inverse agonists: identification of 5-methyl-1-[[2-[(2-methyl-3-pyridyl)oxy]- 5-pyridyl]carbamoyl]-6trifluoromethylindoline (SB-243213) as a potential antidepressant/anxiolytic agent. J. Med. Chem. 43: 1123-34 [PMID:10737744]

70. Brown AM, Avenell K, Young TJ, Ho M, Porter RA, Vimal M and Middlemiss DN. (1998) BRL 54443, a potent agonist with selectivity for human cloned 5-HT1E and 5-HT1F receptors. British Journal of Pharmacology 123: 233

71. Brown AM, Young TJ, Patch TL, Cheung CW, Kaumann AJ, Gaster L and King FD. (1993) $\left.{ }^{125}{ }^{[}\right]-S B$ 207710, A potent, slective radioligand for 5- $\mathrm{HT}_{4}$ receptors. Br J Pharmacol 110: 10

72. Bruinvels AT, Landwehrmeyer B, Gustafson EL, Durkin MM, Mengod G, Branchek TA, Hoyer D and Palacios JM. (1994) Localization of 5-HT1B, 5-HT1D alpha, 5-HT1E and 5-HT1F receptor messenger RNA in rodent and primate brain. Neuropharmacology 33: 367-86 [PMID:7984275]

73. Bruinvels AT, Palacios JM and Hoyer D. (1993) Autoradiographic characterisation and localisation of 5HT1D compared to 5-HT1B binding sites in rat brain. Naunyn Schmiedebergs Arch. Pharmacol. 347: 56982 [PMID:8361548]

74. Bryant HU, Nelson DL, Button D, Cole HW, Baez MB, Lucaites VL, Wainscott DB, Whitesitt C, Reel J and Simon R et al.. (1996) A novel class of 5-HT2A receptor antagonists: aryl aminoguanidines.Life Sci. 59: 1259-68 [PMID:8845011]

75. Brüss M, Kiel S, Bönisch H, Kostanian A and Göthert M. (2005) Decreased agonist, but not antagonist, binding to the naturally occurring Thr92Lys variant of the h5-HT7(a) receptor. Neurochem. Int. 47: 196-203 [PMID:15896881]

76. Buckland PR, Hoogendoorn B, Guy CA, Smith SK, Coleman SL and O'Donovan MC. (2005) Low gene expression conferred by association of an allele of the $5-\mathrm{HT} 2 \mathrm{C}$ receptor gene with antipsychotic-induced weight gain. Am J Psychiatry 162: 613-5 [PMID:15741483]

77. Budhoo MR and Kellum JM. (1994) Evidence for a 5-HT4 receptor pathway mediating chloride secretion in the rat distal colon. J. Surg. Res. 57: 44-8 [PMID:8041147]

78. Buhot MC and Naïli S. (1995) Changes in exploratory activity following stimulation of hippocampal 5-HT1A and 5-HT1B receptors in the rat. Hippocampus 5: 198-208 [PMID:7550615]

79. Burnet PW, Eastwood SL, Lacey K and Harrison PJ. (1995) The distribution of 5-HT1A and 5-HT2A receptor mRNA in human brain. Brain Res. 676: 157-68 [PMID:7796165]

80. Burns CM, Chu H, Rueter SM, Hutchinson LK, Canton H, Sanders-Bush E and Emeson RB. (1997) Regulation of serotonin-2C receptor G-protein coupling by RNA editing. Nature 387: 303-8 [PMID:9153397] 
81. Bymaster FP, Dreshfield-Ahmad LJ, Threlkeld PG, Shaw JL, Thompson L, Nelson DL, Hemrick-Luecke SK and Wong DT. (2001) Comparative affinity of duloxetine and venlafaxine for serotonin and norepinephrine transporters in vitro and in vivo, human serotonin receptor subtypes, and other neuronal receptors.

Neuropsychopharmacology 25: 871-80 [PMID:11750180]

82. Canton H, Emeson RB, Barker EL, Backstrom JR, Lu JT, Chang MS and Sanders-Bush E. (1996) Identification, molecular cloning, and distribution of a short variant of the 5-hydroxytryptamine2C receptor produced by alternative splicing. Mol. Pharmacol. 50: 799-807 [PMID:8863824]

83. Carson MJ, Thomas EA, Danielson PE and Sutcliffe JG. (1996) The 5HT5A serotonin receptor is expressed predominantly by astrocytes in which it inhibits cAMP accumulation: a mechanism for neuronal suppression of reactive astrocytes. Glia 17: 317-26 [PMID:8856328]

84. Castro L, Mialet-Perez J, Guillemeau A, Stillitano F, Zolk O, Eschenhagen T, Lezoualc'h F, Bochet P and Fischmeister R. (2005) Differential functional effects of two 5-HT4 receptor isoforms in adult cardiomyocytes. J. Mol. Cell. Cardiol. 39: 335-44 [PMID:15950987]

85. Centurión D, Glusa E, Sánchez-López A, Valdivia LF, Saxena PR and Villalón CM. (2004) 5-HT7, but not 5-HT2B, receptors mediate hypotension in vagosympathectomized rats. Eur. J. Pharmacol. 502: 239-42 [PMID:15476750]

86. Chadha A, Sur C, Atack J and Duty S. (2000) The 5HT(1B) receptor agonist, CP-93129, inhibits [(3)H]GABA release from rat globus pallidus slices and reverses akinesia following intrapallidal injection in the reserpine-treated rat. Br. J. Pharmacol. 130: 1927-32 [PMID:10952684]

87. Chapin EM and Andrade R. (2001) A 5-HT(7) receptor-mediated depolarization in the anterodorsal thalamus. II. Involvement of the hyperpolarization-activated current I(h). J. Pharmacol. Exp. Ther. 297: 4039 [PMID:11259569]

88. Charest A, Wainer BH and Albert PR. (1993) Cloning and differentiation-induced expression of a murine serotonin1A receptor in a septal cell line. J. Neurosci. 13: 5164-71 [PMID:8254366]

89. Chen J, Shen C and Meller E. (2002) 5-HT1A receptor-mediated regulation of mitogen-activated protein kinase phosphorylation in rat brain. Eur. J. Pharmacol. 452: 155-62 [PMID:12354565]

90. Choi DS and Maroteaux L. (1996) Immunohistochemical localisation of the serotonin 5-HT2B receptor in mouse gut, cardiovascular system, and brain. FEBS Lett. 391: 45-51 [PMID:8706927]

91. Choi S, Haggart D, Toll L and Cuny GD. (2004) Synthesis, receptor binding and functional studies of mesoridazine stereoisomers. Bioorg. Med. Chem. Lett. 14: 4379-82 [PMID:15357957]

92. Chojnacka-Wójcik E, Kłodzińska A and Dereń-Wesołek A. (1994) Involvement of 5-HT2C receptors in the m-CPP-induced antinociception in mice. Pol J Pharmacol 46: 423-8 [PMID:7894529]

93. Chou-Green JM, Holscher TD, Dallman MF and Akana SF. (2003) Repeated stress in young and old 5HT(2C) receptor knockout mice. Physiol. Behav. 79: 217-26 [PMID:12834793]

94. Chou-Green JM, Holscher TD, Dallman MF and Akana SF. (2003) Compulsive behavior in the 5-HT2C receptor knockout mouse. Physiol. Behav. 78: 641-9 [PMID:12782219]

95. Claeysen S, Faye P, Sebben M, Lemaire S, Bockaert $J$ and Dumuis A. (1997) Cloning and expression of human 5-HT4S receptors. Effect of receptor density on their coupling to adenylyl cyclase. Neuroreport 8: 3189-96 [PMID:9351641]

96. Claeysen S, Sebben M, Becamel C, Bockaert J and Dumuis A. (1999) Novel brain-specific 5-HT4 receptor splice variants show marked constitutive activity: role of the C-terminal intracellular domain. $\mathrm{Mol}$.

Pharmacol. 55: 910-20 [PMID:10220570]

97. Claeysen S, Sebben M, Journot L, Bockaert J and Dumuis A. (1996) Cloning, expression and pharmacology of the mouse 5-HT(4L) receptor. FEBS Lett. 398: 19-25 [PMID:8946946]

98. Commery TA. (2010) SAM-531, N,N-dimethyl-3-\{[3-(1-naphthylsulfonyl)-1H-indazol-5-yl]oxy\} propan-1amine, a novel serotonin-6 receptor antagonist with preclinical pro-cognitive efficacy. Alzheimer's \& Dementia 6: S548-S549

99. Compan V, Charnay Y, Dusticier N, Daszuta A, Hen R and Bockaert J. (2004) [Feeding disorders in 5-HT4 receptor knockout mice]. J. Soc. Biol. 198: 37-49 [PMID:15146954]

100. Compan V, Daszuta A, Salin P, Sebben M, Bockaert J and Dumuis A. (1996) Lesion study of the 
distribution of serotonin 5-HT4 receptors in rat basal ganglia and hippocampus. Eur. J. Neurosci. 8: 2591-8 [PMID:8996808]

101. Compan V, Zhou M, Grailhe R, Gazzara RA, Martin R, Gingrich J, Dumuis A, Brunner D, Bockaert J and Hen R. (2004) Attenuated response to stress and novelty and hypersensitivity to seizures in 5-HT4 receptor knock-out mice. J. Neurosci. 24: 412-9 [PMID:14724239]

102. Conn PJ, Sanders-Bush E, Hoffman BJ and Hartig PR. (1986) A unique serotonin receptor in choroid plexus is linked to phosphatidylinositol turnover. Proc. Natl. Acad. Sci. U.S.A. 83: 4086-8 [PMID:2940597]

103. Corbett DF, Heightman TD, Moss SF, Bromidge SM, Coggon SA, Longley MJ, Roa AM, Williams JA and Thomas DR. (2005) Discovery of a potent and selective 5-ht5A receptor antagonist by high-throughput chemistry. Bioorg. Med. Chem. Lett. 15: 4014-8 [PMID:16002289]

104. Costes N, Merlet I, Ostrowsky K, Faillenot I, Lavenne F, Zimmer L, Ryvlin P and Le Bars D. (2005) A 18FMPPF PET normative database of 5-HT1A receptor binding in men and women over aging. J. Nucl. Med.

46: 1980-9 [PMID:16330560]

105. Cox DA and Cohen ML. (1995) 5-Hydroxytryptamine2B receptor signaling in rat stomach fundus: role of voltage-dependent calcium channels, intracellular calcium release and protein kinase C. J. Pharmacol. Exp. Ther. 272: 143-50 [PMID:7815326]

106. Crowell MD, Mathis C, Schettler VA, Yunus T and Lacy BE. (2005) The effects of tegaserod, a 5-HT receptor agonist, on gastric emptying in a murine model of diabetes mellitus. Neurogastroenterol. Motil. 17: 738-43 [PMID:16185313]

107. Darblade B, Behr-Roussel D, Gorny D, Lebret T, Benoit G, Hieble JP, Brooks D, Alexandre L and Giuliano F. (2005) Piboserod (SB 207266), a selective 5-HT4 receptor antagonist, reduces serotonin potentiation of neurally-mediated contractile responses of human detrusor muscle. World J Urol 23: 147-51 [PMID:15902472]

108. Davidson C, Ho M, Price GW, Jones BJ and Stamford JA. (1997) (+)-WAY 100135, a partial agonist, at native and recombinant 5-HT1B/1D receptors. Br. J. Pharmacol. 121: 737-42 [PMID:9208142]

109. Dawson LA and Watson JM. (2009) Vilazodone: a 5-HT1A receptor agonist/serotonin transporter inhibitor for the treatment of affective disorders. CNS Neurosci Ther 15: 107-17 [PMID:19499624]

110. Day M, Olson PA, Platzer J, Striessnig J and Surmeier DJ. (2002) Stimulation of 5-HT(2) receptors in prefrontal pyramidal neurons inhibits $\mathrm{Ca}(\mathrm{v}) 1.2 \mathrm{~L}$ type $\mathrm{Ca}(2+)$ currents via a PLCbeta/IP3/calcineurin signaling cascade. J. Neurophysiol. 87: 2490-504 [PMID:11976386]

111. de las Casas-Engel M, Domínguez-Soto A, Sierra-Filardi E, Bragado R, Nieto C, Puig-Kroger A, Samaniego R, Loza M, Corcuera MT and Gómez-Aguado F et al.. (2013) Serotonin skews human macrophage polarization through HTR2B and HTR7. J. Immunol. 190: 2301-10 [PMID:23355731]

112. De Vry J, Schohe-Loop R, Heine HG, Greuel JM, Mauler F, Schmidt B, Sommermeyer H and Glaser T. (1998) Characterization of the aminomethylchroman derivative BAY $\times 3702$ as a highly potent 5hydroxytryptamine1A receptor agonist. J. Pharmacol. Exp. Ther. 284: 1082-94 [PMID:9495870]

113. Degen L, Matzinger D, Merz M, Appel-Dingemanse S, Osborne S, Lüchinger S, Bertold R, Maecke H and Beglinger C. (2001) Tegaserod, a 5-HT4 receptor partial agonist, accelerates gastric emptying and gastrointestinal transit in healthy male subjects. Aliment. Pharmacol. Ther. 15: 1745-51 [PMID:11683688]

114. Del Tredici AL, Schiffer HH, Burstein ES, Lameh J, Mohell N, Hacksell U, Brann MR and Weiner DM. (2004) Pharmacology of polymorphic variants of the human 5-HT1A receptor. Biochem. Pharmacol. 67: 479-90 [PMID:15037200]

115. Dizeyi N, Bjartell A, Nilsson E, Hansson J, Gadaleanu V, Cross N and Abrahamsson PA. (2004) Expression of serotonin receptors and role of serotonin in human prostate cancer tissue and cell lines. Prostate 59: 328-36 [PMID:15042609]

116. Doly S, Fischer J, Brisorgueil MJ, Vergé D and Conrath M. (2004) 5-HT5A receptor localization in the rat spinal cord suggests a role in nociception and control of pelvic floor musculature. J. Comp. Neurol. 476: 316-29 [PMID:15282708]

117. Doménech T, Beleta J, Fernández AG, Gristwood RW, Cruz Sánchez F, Tolosa E and Palacios JM. (1994) Identification and characterization of serotonin 5-HT4 receptor binding sites in human brain: 
comparison with other mammalian species. Brain Res. Mol. Brain Res. 21: 176-80 [PMID:8164518]

118. Doménech T, Beleta J and Palacios JM. (1997) Characterization of human serotonin $1 \mathrm{D}$ and $1 \mathrm{~B}$ receptors using [3H]-GR-125743, a novel radiolabelled serotonin 5HT1D/1B receptor antagonist. Naunyn Schmiedebergs Arch. Pharmacol. 356: 328-34 [PMID:9303569]

119. Dukat M, Smith C, Herrick-Davis K, Teitler M and Glennon RA. (2004) Binding of tryptamine analogs at h5HT1E receptors: a structure-affinity investigation. Bioorg. Med. Chem. 12: 2545-52 [PMID:15110837]

120. Dumuis A, Bouhelal R, Sebben M, Cory R and Bockaert J. (1988) A nonclassical 5-hydroxytryptamine receptor positively coupled with adenylate cyclase in the central nervous system. Mol. Pharmacol. 34: 8807 [PMID:2849052]

121. Dunlop J, Sabb AL, Mazandarani H, Zhang J, Kalgaonker S, Shukhina E, Sukoff S, Vogel RL, Stack G and Schechter L et al.. (2005) WAY-163909 [(7bR, 10aR)-1,2,3,4,8,9,10,10a-octahydro-7bH-cyclopenta-[b] $[1,4]$ diazepino[6,7,1 hi]indole], a novel 5-hydroxytryptamine $2 \mathrm{C}$ receptor-selective agonist with anorectic activity. J. Pharmacol. Exp. Ther. 313: 862-9 [PMID:15705738]

122. Egan C, Grinde E, Dupre A, Roth BL, Hake M, Teitler M and Herrick-Davis K. (2000) Agonist high and low affinity state ratios predict drug intrinsic activity and a revised ternary complex mechanism at serotonin 5$\mathrm{HT}(2 \mathrm{~A})$ and 5-HT(2C) receptors. Synapse 35: 144-150 [PMID:10611640]

123. Egan CT, Herrick-Davis K and Teitler M. (1998) Creation of a constitutively activated state of the 5hydroxytryptamine2A receptor by site-directed mutagenesis: inverse agonist activity of antipsychotic drugs. J. Pharmacol. Exp. Ther. 286: 85-90 [PMID:9655845]

124. El-Khodor BF, Dimmler MH, Amara DA, Hofer M, Hen R and Brunner D. (2004) Juvenile 5HT(1B) receptor knockout mice exhibit reduced pharmacological sensitivity to $5 \mathrm{HT}(1 \mathrm{~A})$ receptor activation. Int. J. Dev. Neurosci. 22: 405-13 [PMID:15380839]

125. Ellis ES, Byrne C, Murphy OE, Tilford NS and Baxter GS. (1995) Mediation by 5-hydroxytryptamine2B receptors of endothelium-dependent relaxation in rat jugular vein. Br. J. Pharmacol. 114: 400-4 [PMID:7881740]

126. Ennis MD, Ghazal NB, Hoffman RL, Smith MW, Schlachter SK, Lawson CF, Im WB, Pregenzer JF, Svensson KA and Lewis RA et al.. (1998) Isochroman-6-carboxamides as highly selective 5-HT1D agonists: potential new treatment for migraine without cardiovascular side effects. J. Med. Chem. 41: 2180-3 [PMID:9632349]

127. Erlander MG, Lovenberg TW, Baron BM, de Lecea L, Danielson PE, Racke M, Slone AL, Siegel BW, Foye PE and Cannon $\mathrm{K}$ et al.. (1993) Two members of a distinct subfamily of 5-hydroxytryptamine receptors differentially expressed in rat brain. Proc. Natl. Acad. Sci. U.S.A. 90: 3452-6 [PMID:7682702]

128. Fargin A, Raymond JR, Regan JW, Cotecchia S, Lefkowitz RJ and Caron MG. (1989) Effector coupling mechanisms of the cloned 5-HT1A receptor. J. Biol. Chem. 264: 14848-52 [PMID:2549039]

129. Fedouloff M, Hossner F, Voyle M, Ranson J, Powles J, Riley G and Sanger G. (2001) Synthesis and pharmacological activity of metabolites of the 5-HT(4) receptor antagonist SB-207266. Bioorg. Med. Chem. 9: 2119-28 [PMID:11504648]

130. Fernández J, Alonso JM, Andrés JI, Cid JM, Díaz A, Iturrino L, Gil P, Megens A, Sipido VK and Trabanco AA. (2005) Discovery of new tetracyclic tetrahydrofuran derivatives as potential broad-spectrum psychotropic agents. J. Med. Chem. 48: 1709-12 [PMID:15771415]

131. Fiorica-Howells E, Hen R, Gingrich J, Li Z and Gershon MD. (2002) 5-HT(2A) receptors: location and functional analysis in intestines of wild-type and 5-HT(2A) knockout mice. Am. J. Physiol. Gastrointest. Liver Physiol. 282: G877-93 [PMID:11960784]

132. Fiorino F, Magli E, Kędzierska E, Ciano A, Corvino A, Severino B, Perissutti E, Frecentese F, Di Vaio P and Saccone $\mathrm{I}$ et al.. (2017) New 5- $\mathrm{HT}_{1 \mathrm{~A}}, 5 \mathrm{HT}_{2 \mathrm{~A}}$ and $5 \mathrm{HT}_{2 \mathrm{C}}$ receptor ligands containing a picolinic nucleus: Synthesis, in vitro and in vivo pharmacological evaluation. Bioorg. Med. Chem. 25: 5820-5837 [PMID:28943244]

133. Fitzgerald LW, Conklin DS, Krause CM, Marshall AP, Patterson JP, Tran DP, lyer G, Kostich WA, Largent BL and Hartig PR. (1999) High-affinity agonist binding correlates with efficacy (intrinsic activity) at the human serotonin $5-\mathrm{HT} 2 \mathrm{~A}$ and $5-\mathrm{HT} 2 \mathrm{C}$ receptors: evidence favoring the ternary complex and two-state 
models of agonist action. J. Neurochem. 72: 2127-34 [PMID:10217294]

134. Fitzgerald LW, lyer G, Conklin DS, Krause CM, Marshall A, Patterson JP, Tran DP, Jonak GJ and Hartig PR. (1999) Messenger RNA editing of the human serotonin 5-HT2C receptor. Neuropsychopharmacology 21: 82S-90S [PMID:10432493]

135. Foguet M, Nguyen $\mathrm{H}$, Le $\mathrm{H}$ and Lübbert $\mathrm{H}$. (1992) Structure of the mouse 5-HT1C, 5-HT2 and stomach fundus serotonin receptor genes. Neuroreport 3: 345-8 [PMID:1381232]

136. Fone KC, Austin RH, Topham IA, Kennett GA and Punhani T. (1998) Effect of chronic m-CPP on locomotion, hypophagia, plasma corticosterone and 5-HT2C receptor levels in the rat. Br. J. Pharmacol. 123: 1707-15 [PMID:9605579]

137. Fonseca MI, Ni YG, Dunning DD and Miledi R. (2001) Distribution of serotonin 2A, $2 \mathrm{C}$ and 3 receptor mRNA in spinal cord and medulla oblongata. Brain Res. Mol. Brain Res. 89: 11-9 [PMID:11311971]

138. Forbes IT, Douglas S, Gribble AD, Ife RJ, Lightfoot AP, Garner AE, Riley GJ, Jeffrey P, Stevens AJ and Stean TO et al.. (2002) SB-656104-A: a novel 5-HT(7) receptor antagonist with improved in vivo properties. Bioorg. Med. Chem. Lett. 12: 3341-4 [PMID:12392747]

139. Ford AP, Baxter GS, Eglen RM and Clarke DE. (1992) 5-Hydroxytryptamine stimulates cyclic AMP formation in the tunica muscularis mucosae of the rat oesophagus via 5-HT4 receptors. Eur. J. Pharmacol.

211: 117-20 [PMID:1319906]

140. Foxx-Orenstein AE, Kuemmerle JF and Grider JR. (1996) Distinct 5-HT receptors mediate the peristaltic reflex induced by mucosal stimuli in human and guinea pig intestine. Gastroenterology 111: 1281-90 [PMID:8898642]

141. Francken BJ, Jurzak M, Vanhauwe JF, Luyten WH and Leysen JE. (1998) The human 5-ht5A receptor couples to Gi/Go proteins and inhibits adenylate cyclase in HEK 293 cells. Eur. J. Pharmacol. 361: 299309 [PMID:9865521]

142. Frank MG, Stryker MP and Tecott LH. (2002) Sleep and sleep homeostasis in mice lacking the 5-HT2c receptor. Neuropsychopharmacology 27: 869-73 [PMID:12431861]

143. Freire-Garabal M, Núñez MJ, Balboa J, López-Delgado $P$, Gallego R, García-Caballero T, Fernández-Roel MD, Brenlla J and Rey-Méndez M. (2003) Serotonin upregulates the activity of phagocytosis through 5HT1A receptors. Br. J. Pharmacol. 139: 457-63 [PMID:12770951]

144. Fujiwara Y, Nelson DL, Kashihara K, Varga E, Roeske WR and Yamamura HI. (1990) The cloning and sequence analysis of the rat serotonin-1A receptor gene. Life Sci. 47: PL127-32 [PMID:2273937]

145. Gaietta GM, Yoder EJ, Deerinck T, Kinder K, Hanono A, Han A, Wu C and Ellisman MH. (2003) 5-HT2a receptors in rat sciatic nerves and Schwann cell cultures. J. Neurocytol. 32: 373-80 [PMID:14724380]

146. Galeotti N, Ghelardini C and Bartolini A. (1998) Role of 5-HT4 receptors in the mouse passive avoidance test. J. Pharmacol. Exp. Ther. 286: 1115-21 [PMID:9732367]

147. Gardell LR, Vanover KE, Pounds L, Johnson RW, Barido R, Anderson GT, Veinbergs I, Dyssegaard A, Brunmark P and Tabatabaei A et al.. (2007) ACP-103, a 5-hydroxytryptamine 2A receptor inverse agonist, improves the antipsychotic efficacy and side-effect profile of haloperidol and risperidone in experimental models. J. Pharmacol. Exp. Ther. 322: 862-70 [PMID:17519387]

148. Garlow SJ, Chin AC, Marinovich AM, Heller MR and Ciaranello RD. (1994) Cloning and functional promoter mapping of the rat serotonin-2 receptor gene. Mol. Cell. Neurosci. 5: 291-300 [PMID:8087427]

149. Garnovskaya MN, Gettys TW, van Biesen T, Prpic V, Chuprun JK and Raymond JR. (1997) 5-HT1A receptor activates $\mathrm{Na}+/ \mathrm{H}+$ exchange in $\mathrm{CHO}-\mathrm{K} 1$ cells through Gialpha2 and Gialpha3. J. Biol. Chem. 272: 7770-6 [PMID:9065439]

150. Garnovskaya MN, Nebigil CG, Arthur JM, Spurney RF and Raymond JR. (1995) 5-Hydroxytryptamine2A receptors expressed in rat renal mesangial cells inhibit cyclic AMP accumulation. Mol. Pharmacol. 48: 2307 [PMID:7651356]

151. Gaster LM, Blaney FE, Davies S, Duckworth DM, Ham P, Jenkins S, Jennings AJ, Joiner GF, King FD and Mulholland KR et al.. (1998) The selective 5-HT1B receptor inverse agonist 1'-methyl-5-[[2'-methyl-4'-(5methyl-1,2, 4-oxadiazol-3-yl)biphenyl-4-yl]carbonyl]-2,3,6,7-tetrahydro- spiro[furo[2,3-f]indole-3,4'piperidine] (SB-224289) potently blocks terminal 5-HT autoreceptor function both in vitro and in vivo. J. 
Med. Chem. 41: 1218-35 [PMID:9548813]

152. Gerald C, Adham N, Kao HT, Olsen MA, Laz TM, Schechter LE, Bard JA, Vaysse PJ, Hartig PR and Branchek TA et al.. (1995) The 5-HT4 receptor: molecular cloning and pharmacological characterization of two splice variants. EMBO J. 14: 2806-15 [PMID:7796807]

153. Gershon MD. (1999) Review article: roles played by 5-hydroxytryptamine in the physiology of the bowel. Aliment. Pharmacol. Ther. 13 Suppl 2: 15-30 [PMID:10429737]

154. Ghia JE, Li N, Wang H, Collins M, Deng Y, El-Sharkawy RT, Côté F, Mallet J and Khan WI. (2009) Serotonin has a key role in pathogenesis of experimental colitis. Gastroenterology 137: 1649-60 [PMID:19706294]

155. Gibson EL, Barnfield AM and Curzon G. (1994) Evidence that mCPP-induced anxiety in the plus-maze is mediated by postsynaptic 5-HT2C receptors but not by sympathomimetic effects. Neuropharmacology 33: 457-65 [PMID:7984284]

156. Gilet M, Eutamene H, Han H, Kim HW and Bueno L. (2014) Influence of a new 5-HT4 receptor partial agonist, YKP10811, on visceral hypersensitivity in rats triggered by stress and inflammation.

Neurogastroenterol. Motil. 26: 1761-70 [PMID:25316608]

157. Glennon RA. (2003) Higher-end serotonin receptors: 5-HT(5), 5-HT(6), and 5-HT(7).J. Med. Chem. 46: 2795-812 [PMID:12825922]

158. Glennon RA, Lee M, Rangisetty JB, Dukat M, Roth BL, Savage JE, McBride A, Rauser L, Hufeisen S and Lee DK. (2000) 2-Substituted tryptamines: agents with selectivity for 5-HT(6) serotonin receptors. J. Med. Chem. 43: 1011-8 [PMID:10715164]

159. Goodfellow NM, Bailey CD and Lambe EK. (2012) The native serotonin 5-HT(5A) receptor: electrophysiological characterization in rodent cortex and $5-\mathrm{HT}(1 \mathrm{~A})$-mediated compensatory plasticity in the knock-out mouse. J. Neurosci. 32: 5804-9 [PMID:22539842]

160. Grailhe R, Grabtree GW and Hen R. (2001) Human 5-HT(5) receptors: the 5-HT(5A) receptor is functional but the 5-HT(5B) receptor was lost during mammalian evolution. Eur. J. Pharmacol. 418: 157-67 [PMID:11343685]

161. Grailhe R, Waeber C, Dulawa SC, Hornung JP, Zhuang X, Brunner D, Geyer MA and Hen R. (1999) Increased exploratory activity and altered response to LSD in mice lacking the 5-HT(5A) receptor. Neuron 22: 581-91 [PMID:10197537]

162. Grider JR. (2003) Neurotransmitters mediating the intestinal peristaltic reflex in the mouse J. Pharmacol. Exp. Ther. 307: 460-7 [PMID:12966154]

163. Grånäs $C$ and Larhammar D. (1999) Identification of an amino acid residue important for binding of methiothepin and sumatriptan to the human 5-HT(1B) receptor. Eur. J. Pharmacol. 380: 171-81 [PMID:10513577]

164. Guptan P, Dhingra A and Panicker MM. (1997) Multiple transcripts encode the 5-HT1F receptor in rodent brain. Neuroreport 8: 3317-21 [PMID:9351664]

165. Guscott M, Bristow LJ, Hadingham K, Rosahl TW, Beer MS, Stanton JA, Bromidge F, Owens AP, Huscroft I and Myers J et al.. (2005) Genetic knockout and pharmacological blockade studies of the 5-HT7 receptor suggest therapeutic potential in depression. Neuropharmacology 48: 492-502 [PMID:15755477]

166. Guscott MR, Egan E, Cook GP, Stanton JA, Beer MS, Rosahl TW, Hartmann S, Kulagowski J, McAllister $G$ and Fone KC et al.. (2003) The hypothermic effect of 5-CT in mice is mediated through the 5-HT7 receptor. Neuropharmacology 44: 1031-7 [PMID:12763096]

167. Hall H, Farde L, Halldin C, Lundkvist C and Sedvall G. (2000) Autoradiographic localization of 5-HT(2A) receptors in the human brain using [(3)H]M100907 and [(11)C]M100907. Synapse 38: 421-31 [PMID:11044889]

168. Hamada S, Senzaki K, Hamaguchi-Hamada K, Tabuchi K, Yamamoto H, Yamamoto T, Yoshikawa S, Okano H and Okado N. (1998) Localization of 5-HT2A receptor in rat cerebral cortex and olfactory system revealed by immunohistochemistry using two antibodies raised in rabbit and chicken. Brain Res. Mol. Brain Res. 54: 199-211 [PMID:9555012]

169. Hamblin MW, McGuffin RW, Metcalf MA, Dorsa DM and Merchant KM. (1992) Distinct 5-HT1B and 5- 
HT1D serotonin receptors in rat: structural and pharmacological comparison of the two cloned receptors. Mol. Cell. Neurosci. 3: 578-587

170. Hamblin MW and Metcalf MA. (1991) Primary structure and functional characterization of a human 5HT1D-type serotonin receptor. Mol. Pharmacol. 40: 143-8 [PMID:1652050]

171. Hamblin MW, Metcalf MA, McGuffin RW and Karpells S. (1992) Molecular cloning and functional characterization of a human 5-HT1B serotonin receptor: a homologue of the rat 5-HT1B receptor with 5HT1D-like pharmacological specificity. Biochem. Biophys. Res. Commun. 184: 752-9 [PMID:1315531]

172. Hameg A, Bayle F, Nuss P, Dupuis P, Garay RP and Dib M. (2003) Affinity of cyamemazine, an anxiolytic antipsychotic drug, for human recombinant dopamine vs. serotonin receptor subtypes. Biochem. Pharmacol. 65: 435-40 [PMID:12527336]

173. Hannon J and Hoyer D. (2008) Molecular biology of 5-HT receptors.Behav. Brain Res. 195: 198-213 [PMID:18571247]

174. Harada K, Aota M, Inoue T, Matsuda R, Mihara T, Yamaji T, Ishibashi K and Matsuoka N. (2006) Anxiolytic activity of a novel potent serotonin 5-HT2C receptor antagonist FR260010: a comparison with diazepam and buspirone. Eur. J. Pharmacol. 553: 171-84 [PMID:17074317]

175. Harte SE, Kender RG and Borszcz GS. (2005) Activation of 5-HT1A and 5-HT7 receptors in the parafascicular nucleus suppresses the affective reaction of rats to noxious stimulation. Pain 113: 405-15 [PMID:15661450]

176. Hartig PR, Hoyer D, Humphrey PP and Martin GR. (1996) Alignment of receptor nomenclature with the human genome: classification of 5-HT1B and 5-HT1D receptor subtypes. Trends Pharmacol. Sci. 17: 1035 [PMID:8936345]

177. Hasegawa Y, Higuchi S, Matsushita S and Miyaoka H. (2002) Association of a polymorphism of the serotonin $1 \mathrm{~B}$ receptor gene and alcohol dependence with inactive aldehyde dehydrogenase-2. $J$ Neural Transm (Vienna) 109: 513-21 [PMID:11956970]

178. Hawi Z, Dring M, Kirley A, Foley D, Kent L, Craddock N, Asherson P, Curran S, Gould A and Richards Set al.. (2002) Serotonergic system and attention deficit hyperactivity disorder (ADHD): a potential susceptibility locus at the $5-\mathrm{HT}(1 \mathrm{~B})$ receptor gene in 273 nuclear families from a multi-centre sample. Mol. Psychiatry 7: 718-25 [PMID:12192616]

179. Hedlund PB, Carson MJ, Sutcliffe JG and Thomas EA. (1999) Allosteric regulation by oleamide of the binding properties of 5-hydroxytryptamine7 receptors. Biochem. Pharmacol. 58: 1807-13 [PMID:10571256]

180. Hedlund PB, Kelly L, Mazur C, Lovenberg T, Sutcliffe JG and Bonaventure P. (2004) 8-OH-DPAT acts on both 5-HT1A and 5-HT7 receptors to induce hypothermia in rodents. Eur. J. Pharmacol. 487: 125-32 [PMID:15033384]

181. Hegde SS and Eglen RM. (1996) Peripheral 5-HT4 receptors.FASEB J. 10: 1398-407 [PMID:8903510]

182. Hegde SS, Wong AG, Perry MR, Ku P, Moy TM, Loeb M and Eglen RM. (1995) 5-HT4 receptor mediated stimulation of gastric emptying in rats. Naunyn Schmiedebergs Arch. Pharmacol. 351: 589-95 [PMID:7675116]

183. Heidmann DE, Szot P, Kohen R and Hamblin MW. (1998) Function and distribution of three rat 5hydroxytryptamine7 (5-HT7) receptor isoforms produced by alternative splicing. Neuropharmacology 37: 1621-32 [PMID:9886685]

184. Heinrich T, Böttcher H, Gericke R, Bartoszyk GD, Anzali S, Seyfried CA, Greiner HE and Van Amsterdam C. (2004) Synthesis and structure--activity relationship in a class of indolebutylpiperazines as dual 5$\mathrm{HT}(1 \mathrm{~A})$ receptor agonists and serotonin reuptake inhibitors. J. Med. Chem. 47: 4684-92 [PMID:15341484]

185. Heisler LK, Chu HM, Brennan TJ, Danao JA, Bajwa P, Parsons LH and Tecott LH. (1998) Elevated anxiety and antidepressant-like responses in serotonin 5-HT1A receptor mutant mice. Proc. Natl. Acad. Sci. U.S.A. 95: 15049-54 [PMID:9844013]

186. Herrick-Davis K, Egan C and Teitler M. (1997) Activating mutations of the serotonin 5-HT2C receptorJ. Neurochem. 69: 1138-44 [PMID:9282936]

187. Herrick-Davis K, Grinde E and Niswender CM. (1999) Serotonin 5-HT2C receptor RNA editing alters receptor basal activity: implications for serotonergic signal transduction. J. Neurochem. 73: 1711-7 
[PMID:10501219]

188. Herrick-Davis K, Grinde E and Teitler M. (2000) Inverse agonist activity of atypical antipsychotic drugs at human 5-hydroxytryptamine2C receptors. J. Pharmacol. Exp. Ther. 295: 226-32 [PMID:10991983]

189. Heusler P, Palmier C, Tardif S, Bernois S, Colpaert FC and Cussac D. (2010) [(3)H]-F13640, a novel, selective and high-efficacy serotonin $5-\mathrm{HT}(1 \mathrm{~A})$ receptor agonist radioligand. Naunyn Schmiedebergs Arch. Pharmacol. 382: 321-30 [PMID:20799027]

190. Hirst WD, Minton JA, Bromidge SM, Moss SF, Latter AJ, Riley G, Routledge C, Middlemiss DN and Price GW. (2000) Characterization of [(125)l]-SB-258585 binding to human recombinant and native 5-HT(6) receptors in rat, pig and human brain tissue. Br. J. Pharmacol. 130: 1597-605 [PMID:10928963]

191. Hirst WD, Stean TO, Rogers DC, Sunter D, Pugh P, Moss SF, Bromidge SM, Riley G, Smith DR and Bartlett S et al.. (2006) SB-399885 is a potent, selective 5-HT6 receptor antagonist with cognitive enhancing properties in aged rat water maze and novel object recognition models. Eur. J. Pharmacol. 553: 109-19 [PMID:17069795]

192. Holenz J, Mercè R, Díaz JL, Guitart X, Codony X, Dordal A, Romero G, Torrens A, Mas J and Andaluz B et al.. (2005) Medicinal chemistry driven approaches toward novel and selective serotonin 5-HT6 receptor ligands. J. Med. Chem. 48: 1781-95 [PMID:15771424]

193. Hou M, Kanje M, Longmore J, Tajti J, Uddman R and Edvinsson L. (2001) 5-HT(1B) and 5-HT(1D) receptors in the human trigeminal ganglion: co-localization with calcitonin gene-related peptide, substance P and nitric oxide synthase. Brain Res. 909: 112-20 [PMID:11478927]

194. Hoyer D, Clarke DE, Fozard JR, Hartig PR, Martin GR, Mylecharane EJ, Saxena PR and Humphrey PP. (1994) International Union of Pharmacology classification of receptors for 5-hydroxytryptamine (Serotonin). Pharmacol. Rev. 46: 157-203 [PMID:7938165]

195. Hoyer D, Hannon JP and Martin GR. (2002) Molecular, pharmacological and functional diversity of 5-HT receptors. Pharmacol. Biochem. Behav. 71: 533-54 [PMID:11888546]

196. Huang YY, Oquendo MA, Friedman JM, Greenhill LL, Brodsky B, Malone KM, Khait V and Mann JJ. (2003) Substance abuse disorder and major depression are associated with the human 5-HT1B receptor gene (HTR1B) G861C polymorphism. Neuropsychopharmacology 28: 163-9 [PMID:12496953]

197. Hurley PT, McMahon RA, Fanning P, O'Boyle KM, Rogers M and Martin F. (1998) Functional coupling of a recombinant human 5-HT5A receptor to G-proteins in HEK-293 cells. Br. J. Pharmacol. 124: 1238-44 [PMID:9720796]

198. Ishibashi T, Horisawa T, Tokuda K, Ishiyama T, Ogasa M, Tagashira R, Matsumoto K, Nishikawa H, Ueda $Y$ and Toma S et al.. (2010) Pharmacological profile of lurasidone, a novel antipsychotic agent with potent 5-hydroxytryptamine 7 (5-HT7) and 5-HT1A receptor activity. J. Pharmacol. Exp. Ther. 334: 171-81 [PMID:20404009]

199. Jasper JR, Kosaka A, To ZP, Chang DJ and Eglen RM. (1997) Cloning, expression and pharmacology of a truncated splice variant of the human 5-HT7 receptor (h5-HT7b). Br. J. Pharmacol. 122: 126-32 [PMID:9298538]

200. Jerning E, Svantesson GT and Mohell N. (1998) Receptor binding characteristics of [3H]NAD-299, a new selective 5-HT1A receptor antagonist. Eur. J. Pharmacol. 360: 219-25 [PMID:9851589]

201. Jin H, Oksenberg D, Ashkenazi A, Peroutka SJ, Duncan AM, Rozmahel R, Yang Y, Mengod G, Palacios JM and O'Dowd BF. (1992) Characterization of the human 5-hydroxytryptamine1B receptor. J. Biol. Chem. 267: 5735-8 [PMID:1348246]

202. Johansson L, Sohn D, Thorberg SO, Jackson DM, Kelder D, Larsson LG, Rényi L, Ross SB, Wallsten C and Eriksson $\mathrm{H}$ et al.. (1997) The pharmacological characterization of a novel selective 5hydroxytryptamine1A receptor antagonist, NAD-299. J. Pharmacol. Exp. Ther. 283: 216-25 [PMID:9336327]

203. John GW, Pauwels PJ, Perez M, Halazy S, Le Grand B, Verscheure Y, Valentin JP, Palmier C, Wurch T and Chopin $\mathrm{P}$ et al.. (1999) F 11356, a novel 5-hydroxytryptamine (5-HT) derivative with potent, selective, and unique high intrinsic activity at 5-HT1B/1D receptors in models relevant to migraine. J. Pharmacol. Exp. Ther. 290: 83-95 [PMID:10381763] 
204. Johnson MP, Loncharich RJ, Baez M and Nelson DL. (1994) Species variations in transmembrane region $\mathrm{V}$ of the 5-hydroxytryptamine type $2 \mathrm{~A}$ receptor alter the structure-activity relationship of certain ergolines and tryptamines. Mol. Pharmacol. 45: 277-86 [PMID:8114677]

205. Johnson SW, Mercuri NB and North RA. (1992) 5-hydroxytryptamine1B receptors block the GABAB synaptic potential in rat dopamine neurons. J. Neurosci. 12: 2000-6 [PMID:1578282]

206. Jorand-Lebrun C, Pauwels PJ, Palmier C, Moret C, Chopin P, Perez M, Marien M and Halazy S. (1997) 5HT1B receptor antagonist properties of novel arylpiperazide derivatives of 1-naphthylpiperazine. J. Med.

Chem. 40: 3974-8 [PMID:9397179]

207. Joubert L, Claeysen S, Sebben M, Bessis AS, Clark RD, Martin RS, Bockaert J and Dumuis A. (2002) A 5HT4 receptor transmembrane network implicated in the activity of inverse agonists but not agonists. J. Biol. Chem. 277: 25502-11 [PMID:11976337]

208. Kadowaki M, Wang XO, Shimatani H, Yoneda S and Takaki M. (2002) 5-HT4 receptor enhances the propulsive power of the peristaltic reflex in the rat distal colon. Auton Neurosci 99: 62-5 [PMID:12171259]

209. Kalipatnapu S, Pucadyil TJ, Harikumar KG and Chattopadhyay A. (2004) Ligand binding characteristics of the human serotonin1A receptor heterologously expressed in $\mathrm{CHO}$ cells. Biosci. Rep. 24: 101-15 [PMID:15628665]

210. Kalkman HO, Subramanian N and Hoyer D. (2001) Extended radioligand binding profile of iloperidone: a broad spectrum dopamine/serotonin/norepinephrine receptor antagonist for the management of psychotic disorders. Neuropsychopharmacology 25: 904-14 [PMID:11750183]

211. Kaumann AJ and Sanders L. (1994) 5-Hydroxytryptamine causes rate-dependent arrhythmias through 5HT4 receptors in human atrium: facilitation by chronic beta-adrenoceptor blockade. Naunyn Schmiedebergs Arch. Pharmacol. 349: 331-7 [PMID:7914677]

212. Kaumann AJ, Sanders L, Brown AM, Murray KJ and Brown MJ. (1990) A 5-hydroxytryptamine receptor in human atrium. Br. J. Pharmacol. 100: 879-85 [PMID:2169944]

213. Kawano H, Tsuji H, Nishimura H, Kimura S, Yano S, Ukimura N, Kunieda Y, Yoshizumi M, Sugano T and Nakagawa K et al.. (2001) Serotonin induces the expression of tissue factor and plasminogen activator inhibitor-1 in cultured rat aortic endothelial cells. Blood 97: 1697-702 [PMID:11238110]

214. Kaya N, Shen T, Lu SG, Zhao FL and Herness S. (2004) A paracrine signaling role for serotonin in rat taste buds: expression and localization of serotonin receptor subtypes. Am. J. Physiol. Regul. Integr. Comp. Physiol. 286: R649-58 [PMID:14715493]

215. Kellett DO, Ramage AG and Jordan D. (2005) Central 5-HT7 receptors are critical for reflex activation of cardiac vagal drive in anaesthetized rats. J. Physiol. (Lond.) 563: 319-31 [PMID:15611034]

216. Kemp A and Manahan-Vaughan D. (2005) The 5-hydroxytryptamine4 receptor exhibits frequencydependent properties in synaptic plasticity and behavioural metaplasticity in the hippocampal CA1 region in vivo. Cereb. Cortex 15: 1037-43 [PMID:15537670]

217. Kennett GA, Wood MD, Bright F, Cilia J, Piper DC, Gager T, Thomas D, Baxter GS, Forbes IT and Ham P et al.. (1996) In vitro and in vivo profile of SB 206553, a potent 5-HT2C/5-HT2B receptor antagonist with anxiolytic-like properties. Br. J. Pharmacol. 117: 427-434 [PMID:8821530]

218. Kennett GA, Wood MD, Bright F, Trail B, Riley G, Holland V, Avenell KY, Stean T, Upton N and Bromidge $S$ et al.. (1997) SB 242084, a selective and brain penetrant 5-HT2C receptor antagonist. Neuropharmacology 36: 609-20 [PMID:9225286]

219. Khawaja X, Ennis $C$ and Minchin MC. (1997) Pharmacological characterization of recombinant human 5hydroxytryptamine1A receptors using a novel antagonist radioligand, [3H]WAY-100635. Life Sci. 60: 65365 [PMID:9048968]

220. Kikuchi C, Nagaso H, Hiranuma T and Koyama M. (1999) Tetrahydrobenzindoles: selective antagonists of the 5-HT7 receptor. J. Med. Chem. 42: 533-5 [PMID:10052959]

221. Kim JJ, Bridle BW, Ghia JE, Wang H, Syed SN, Manocha MM, Rengasamy P, Shajib MS, Wan $Y$ and Hedlund PB et al.. (2013) Targeted inhibition of serotonin type 7 (5-HT7) receptor function modulates immune responses and reduces the severity of intestinal inflammation. J. Immunol. 190: 4795-804 [PMID:23554310] 
222. Kim Y, Kim J, Tae J, Roth BL, Rhim H, Keum G, Nam G and Choo H. (2013) Discovery of aryl-biphenyl-2ylmethylpiperazines as novel scaffolds for $5-\mathrm{HT}(7)$ ligands and role of the aromatic substituents in binding to the target receptor. Bioorg. Med. Chem. 21: 2568-76 [PMID:23541835]

223. Kimura Y, Hatanaka K, Naitou Y, Maeno K, Shimada I, Koakutsu A, Wanibuchi F and Yamaguchi T. (2004) Pharmacological profile of YM348, a novel, potent and orally active 5-HT2C receptor agonist. Eur. J. Pharmacol. 483: 37-43 [PMID:14709324]

224. Klein MT, Dukat M, Glennon RA and Teitler M. (2011) Toward selective drug development for the human 5-hydroxytryptamine $1 \mathrm{E}$ receptor: a comparison of 5-hydroxytryptamine $1 \mathrm{E}$ and $1 \mathrm{~F}$ receptor structureaffinity relationships. J. Pharmacol. Exp. Ther. 337: 860-7 [PMID:21422162]

225. Knight AR, Misra A, Quirk K, Benwell K, Revell D, Kennett G and Bickerdike M. (2004) Pharmacological characterisation of the agonist radioligand binding site of $5-\mathrm{HT}(2 \mathrm{~A}), 5-\mathrm{HT}(2 \mathrm{~B})$ and $5-\mathrm{HT}(2 \mathrm{C})$ receptors. Naunyn Schmiedebergs Arch. Pharmacol. 370: 114-23 [PMID:15322733]

226. Koe BK, Nielsen JA, Macor JE and Heym J. (1992) Biochemical and behavioural studies of the $5-\mathrm{HT}_{\mathrm{B}}$ receptor agonist, CP-94,253. Drug Development Research 26: 241-250

227. Kohen R, Fashingbauer LA, Heidmann DE, Guthrie CR and Hamblin MW. (2001) Cloning of the mouse 5HT6 serotonin receptor and mutagenesis studies of the third cytoplasmic loop. Brain Res. Mol. Brain Res. 90: 110-7 [PMID:11406289]

228. Kohen R, Metcalf MA, Khan N, Druck T, Huebner K, Lachowicz JE, Meltzer HY, Sibley DR, Roth BL and Hamblin MW. (1996) Cloning, characterization, and chromosomal localization of a human 5-HT6 serotonin receptor. J. Neurochem. 66: 47-56 [PMID:8522988]

229. Kongsamut S, Kang J, Chen XL, Roehr J and Rampe D. (2002) A comparison of the receptor binding and HERG channel affinities for a series of antipsychotic drugs. Eur. J. Pharmacol. 450: 37-41 [PMID:12176106]

230. Kongsamut S, Roehr JE, Cai J, Hartman HB, Weissensee P, Kerman LL, Tang L and Sandrasagra A. (1996) lloperidone binding to human and rat dopamine and 5-HT receptors. Eur. J. Pharmacol. 317: 41723 [PMID:8997630]

231. Kovács A, Gacsályi I, Wellmann J, Schmidt E, Szücs Z, Dubreuil V, Nicolas JP, Boutin J, Bózsing D and Egyed A et al.. (2003) Effects of EGIS-7625, a selective and competitive 5-HT2B receptor antagonist. Cardiovasc Drugs Ther 17: 427-34 [PMID:15107597]

232. Krobert KA, Bach T, Syversveen T, Kvingedal AM and Levy FO. (2001) The cloned human 5-HT7 receptor splice variants: a comparative characterization of their pharmacology, function and distribution. Naunyn Schmiedebergs Arch. Pharmacol. 363: 620-32 [PMID:11414657]

233. Krobert KA and Levy FO. (2002) The human 5-HT7 serotonin receptor splice variants: constitutive activity and inverse agonist effects. Br. J. Pharmacol. 135: 1563-71 [PMID:11906971]

234. Kroeze WK, Hufeisen SJ, Popadak BA, Renock SM, Steinberg S, Ernsberger P, Jayathilake K, Meltzer $\mathrm{HY}$ and Roth BL. (2003) H1-histamine receptor affinity predicts short-term weight gain for typical and atypical antipsychotic drugs. Neuropsychopharmacology 28: 519-26 [PMID:12629531]

235. Krogsgaard-Larsen N, Jensen AA, Schrøder TJ, Christoffersen CT and Kehler J. (2014) Novel azaanalogous ergoline derived scaffolds as potent serotonin $5-\mathrm{HT}_{6}$ and dopamine $\mathrm{D}_{2}$ receptor ligands. J. Med. Chem. 57: 5823-8 [PMID:24878269]

236. Kulla A and Manahan-Vaughan D. (2002) Modulation by serotonin 5-HT(4) receptors of long-term potentiation and depotentiation in the dentate gyrus of freely moving rats. Cereb. Cortex 12: 150-62 [PMID:11739263]

237. Kursar JD, Nelson DL, Wainscott DB and Baez M. (1994) Molecular cloning, functional expression, and mRNA tissue distribution of the human 5-hydroxytryptamine2B receptor. Mol. Pharmacol. 46: 227-34 [PMID:8078486]

238. Kursar JD, Nelson DL, Wainscott DB, Cohen ML and Baez M. (1992) Molecular cloning, functional expression, and pharmacological characterization of a novel serotonin receptor (5-hydroxytryptamine2F) from rat stomach fundus. Mol. Pharmacol. 42: 549-57 [PMID:1331748]

239. Kushnir-Sukhov NM, Gilfillan AM, Coleman JW, Brown JM, Bruening S, Toth M and Metcalfe DD. (2006) 
5-hydroxytryptamine induces mast cell adhesion and migration. J. Immunol. 177: 6422-32

[PMID:17056574]

240. Kusserow H, Davies B, Hörtnagl H, Voigt I, Stroh T, Bert B, Deng DR, Fink H, Veh RW and Theuring F. (2004) Reduced anxiety-related behaviour in transgenic mice overexpressing serotonin $1 \mathrm{~A}$ receptors. Brain Res. Mol. Brain Res. 129: 104-16 [PMID:15469887]

241. Lacroix LP, Dawson LA, Hagan JJ and Heidbreder CA. (2004) 5-HT6 receptor antagonist SB-271046 enhances extracellular levels of monoamines in the rat medial prefrontal cortex. Synapse 51: 158-64 [PMID:14618683]

242. Lam S, Shen Y, Nguyen T, Messier TL, Brann M, Comings D, George SR and O'Dowd BF. (1996) A serotonin receptor gene (5HT1A) variant found in a Tourette's syndrome patient. Biochem. Biophys. Res. Commun. 219: 853-8 [PMID:8645269]

243. Langlois M and Fischmeister R. (2003) 5-HT4 receptor ligands: applications and new prospects.J. Med. Chem. 46: 319-44 [PMID:12540230]

244. Laporte AM, Doyen C, Nevo IT, Chauveau J, Hauw JJ and Hamon M. (1996) Autoradiographic mapping of serotonin 5-HT1A, 5-HT1D, 5-HT2A and 5-HT3 receptors in the aged human spinal cord. J. Chem. Neuroanat. 11: 67-75 [PMID:8841890]

245. Launay JM, Birraux G, Bondoux D, Callebert J, Choi DS, Loric S and Maroteaux L. (1996) Ras involvement in signal transduction by the serotonin 5-HT2B receptor. J. Biol. Chem. 271: 3141-7 [PMID:8621713]

246. Law H, Dukat M, Teitler M, Lee DK, Mazzocco L, Kamboj R, Rampersad V, Prisinzano T and Glennon RA. (1998) Benzylimidazolines as h5-HT1B/1D serotonin receptor ligands: a structure-affinity investigation. J. Med. Chem. 41: 2243-51 [PMID:9632357]

247. Lawler CP, Prioleau C, Lewis MM, Mak C, Jiang D, Schetz JA, Gonzalez AM, Sibley DR and Mailman RB. (1999) Interactions of the novel antipsychotic aripiprazole (OPC-14597) with dopamine and serotonin receptor subtypes. Neuropsychopharmacology 20: 612-27 [PMID:10327430]

248. Le Coniat M, Choi DS, Maroteaux L, Launay JM and Berger R. (1996) The 5-HT2B receptor gene maps to 2q36.3-2q37.1. Genomics 32: 172-3 [PMID:8786115]

249. Lee MD, Kennett GA, Dourish CT and Clifton PG. (2002) 5-HT1B receptors modulate components of satiety in the rat: behavioural and pharmacological analyses of the selective serotonin1B agonist CP94,253. Psychopharmacology (Berl.) 164: 49-60 [PMID:12373419]

250. Lefebvre H, Gonzalez KN, Contesse V, Delarue C, Vaudry H and Kuhnl JM. (1998) Effect of prolonged administration of the serotonin $4(5-\mathrm{HT} 4)$ receptor agonist cisapride on aldosterone secretion in healthy volunteers. Endocr. Res. 24: 749-52 [PMID:9888571]

251. Lejeune F, Newman-Tancredi A, Audinot $V$ and Millan MJ. (1997) Interactions of (+)- and (-)-8- and 7hydroxy-2-(di-n-propylamino)tetralin at human (h)D3, hD2 and h serotonin1A receptors and their modulation of the activity of serotoninergic and dopaminergic neurones in rats. J. Pharmacol. Exp. Ther. 280: $1241-9$ [PMID:9067310]

252. Leonardi A, Guarneri L, Poggesi E, Angelico P, Velasco C, Cilia A and Testa R. (2001) N-[2-[4-(2methoxyphenyl)-1-piperazinyl]ethyl]- $\mathrm{N}$-(2-nitrophenyl) cyclohexanecarboxamide: a novel pre- and postsynaptic 5-hydroxytryptamine $(1 \mathrm{~A})$ receptor antagonist active on the lower urinary tract. J. Pharmacol. Exp. Ther. 299: 1027-37 [PMID:11714892]

253. Leopoldo M, Lacivita E, Contino M, Colabufo NA, Berardi F and Perrone R. (2007) Structure-activity relationship study on $\mathrm{N}$-(1,2,3,4-tetrahydronaphthalen-1-yl)-4-aryl-1-piperazinehexanamides, a class of 5HT7 receptor agents. 2. J. Med. Chem. 50: 4214-21 [PMID:17649988]

254. Leopoldo M, Lacivita E, De Giorgio P, Fracasso C, Guzzetti S, Caccia S, Contino M, Colabufo NA, Berardi F and Perrone R. (2008) Structural modifications of N-(1,2,3,4-tetrahydronaphthalen-1-yl)-4-aryl-1piperazinehexanamides: influence on lipophilicity and 5-HT7 receptor activity. Part III. J. Med. Chem. 51: 5813-22 [PMID:18800769]

255. Lesage AS, Wouters R, Van Gompel P, Heylen L, Vanhoenacker P, Haegeman G, Luyten WH and Leysen JE. (1998) Agonistic properties of alniditan, sumatriptan and dihydroergotamine on human 5-HT1B and 5- 
HT1D receptors expressed in various mammalian cell lines. Br. J. Pharmacol. 123: 1655-65

[PMID:9605573]

256. Levy FO, Holtgreve-Grez H, Taskén K, Solberg R, Ried T and Gudermann T. (1994) Assignment of the gene encoding the 5-HT1E serotonin receptor (S31) (locus HTR1E) to human chromosome 6q14-q15. Genomics 22: 637-40 [PMID:8001977]

257. Leysen JE, Gommeren W, Heylen L, Luyten WH, Van de Weyer I, Vanhoenacker P, Haegeman G, Schotte A, Van Gompel P and Wouters R et al.. (1996) Alniditan, a new 5-hydroxytryptamine1D agonist and migraine-abortive agent: ligand-binding properties of human 5-hydroxytryptamine1D alpha, human 5hydroxytryptamine1D beta, and calf 5-hydroxytryptamine1D receptors investigated with [3H]5hydroxytryptamine and [3H]alniditan. Mol. Pharmacol. 50: 1567-80 [PMID:8967979]

258. Li N, Ghia JE, Wang H, McClemens J, Cote F, Suehiro Y, Mallet J and Khan WI. (2011) Serotonin activates dendritic cell function in the context of gut inflammation. Am. J. Pathol. 178: 662-71 [PMID:21281798]

259. Li N, Wallén NH, Ladjevardi M and Hjemdahl P. (1997) Effects of serotonin on platelet activation in whole blood. Blood Coagul. Fibrinolysis 8: 517-23 [PMID:9491270]

260. Li P, Zhang Q, Robichaud AJ, Lee T, Tomesch J, Yao W, Beard JD, Snyder GL, Zhu H and Peng Yet al.. (2014) Discovery of a tetracyclic quinoxaline derivative as a potent and orally active multifunctional drug candidate for the treatment of neuropsychiatric and neurological disorders. J. Med. Chem. 57: 2670-82 [PMID:24559051]

261. Li Q, Holmes A, Ma L, Van de Kar LD, Garcia F and Murphy DL. (2004) Medial hypothalamic 5hydroxytryptamine $(5-\mathrm{HT}) 1 \mathrm{~A}$ receptors regulate neuroendocrine responses to stress and exploratory locomotor activity: application of recombinant adenovirus containing 5-HT1A sequences. J. Neurosci. 24: 10868-77 [PMID:15574737]

262. Lin SL, Setya S, Johnson-Farley NN and Cowen DS. (2002) Differential coupling of 5-HT(1) receptors to G proteins of the G(i) family. Br. J. Pharmacol. 136: 1072-8 [PMID:12145108]

263. Liu M, Geddis MS, Wen Y, Setlik W and Gershon MD. (2005) Expression and function of 5-HT4 receptors in the mouse enteric nervous system. Am. J. Physiol. Gastrointest. Liver Physiol. 289: G1148-63 [PMID:16037544]

264. Long DD, Armstrong SR, Beattie DT, Choi SK, Fatheree PR, Gendron RA, Genov D, Goldblum AA, Humphrey PP and Jiang L et al.. (2012) Discovery, oral pharmacokinetics and in vivo efficacy of velusetrag, a highly selective $5-\mathrm{HT}(4)$ receptor agonist that has achieved proof-of-concept in patients with chronic idiopathic constipation. Bioorg. Med. Chem. Lett. 22: 6048-52 [PMID:22959244]

265. Lopez-Gimenez JF, Villazon M, Brea J, Loza MI, Palacios JM, Mengod G and Vilaro MT. (2001) Multiple conformations of native and recombinant human 5-hydroxytryptamine(2a) receptors are labeled by agonists and discriminated by antagonists. Mol Pharmacol 60: 690-699 [PMID:11562430]

266. Loric S, Launay JM, Colas JF and Maroteaux L. (1992) New mouse 5-HT2-like receptor. Expression in brain, heart and intestine. FEBS Lett. 312: 203-7 [PMID:1426253]

267. Loric S, Maroteaux L, Kellermann O and Launay JM. (1995) Functional serotonin-2B receptors are expressed by a teratocarcinoma-derived cell line during serotoninergic differentiation. Mol. Pharmacol. 47: 458-66 [PMID:7700243]

268. Lovenberg TW, Baron BM, de Lecea L, Miller JD, Prosser RA, Rea MA, Foye PE, Racke M, Slone AL and Siegel BW et al.. (1993) A novel adenylyl cyclase-activating serotonin receptor (5-HT7) implicated in the regulation of mammalian circadian rhythms. Neuron 11: 449-58 [PMID:8398139]

269. Lovenberg TW, Erlander MG, Baron BM, Racke M, Slone AL, Siegel BW, Craft CM, Burns JE, Danielson PE and Sutcliffe JG. (1993) Molecular cloning and functional expression of 5-HT1E-like rat and human 5hydroxytryptamine receptor genes. Proc. Natl. Acad. Sci. U.S.A. 90: 2184-8 [PMID:8384716]

270. Lucaites VL, Nelson DL, Wainscott DB and Baez M. (1996) Receptor subtype and density determine the coupling repertoire of the 5-HT2 receptor subfamily. Life Sci. 59: 1081-95 [PMID:8809227]

271. Lucas JJ, Segu L and Hen R. (1997) 5-Hydroxytryptamine1B receptors modulate the effect of cocaine on c-fos expression: converging evidence using 5-hydroxytryptamine1B knockout mice and the 5- 
hydroxytryptamine1B/1D antagonist GR127935. Mol. Pharmacol. 51: 755-63 [PMID:9145913]

272. López-Meraz ML, González-Trujano ME, Neri-Bazán L, Hong E and Rocha LL. (2005) 5-HT1A receptor agonists modify epileptic seizures in three experimental models in rats. Neuropharmacology 49: 367-75 [PMID:15993434]

273. Ma QP. (2001) Co-localization of 5-HT(1B/1D/1F) receptors and glutamate in trigeminal ganglia in rats. Neuroreport 12: 1589-91 [PMID:11409721]

274. Madjid N, Tottie EE, Lüttgen M, Meister B, Sandin J, Kuzmin A, Stiedl O and Ogren SO. (2006) 5Hydroxytryptamine $1 \mathrm{~A}$ receptor blockade facilitates aversive learning in mice: interactions with cholinergic and glutamatergic mechanisms. J. Pharmacol. Exp. Ther. 316: 581-91 [PMID:16223872]

275. Madsen K, Marner L, Haahr M, Gillings N and Knudsen GM. (2011) Mass dose effects and in vivo affinity in brain PET receptor studies--a study of cerebral 5-HT4 receptor binding with [11C]SB207145. Nucl. Med. Biol. 38: 1085-91 [PMID:21831646]

276. Maier DL, Sobotka-Briner C, Ding M, Powell ME, Jiang Q, Hill G, Heys JR, Elmore CS, Pierson ME and Mrzljak L. (2009) [N-methyl-3H3]AZ10419369 binding to the 5-HT1B receptor: in vitro characterization and in vivo receptor occupancy. J. Pharmacol. Exp. Ther. 330: 342-51 [PMID:19401496]

277. Maillet M, Robert SJ, Cacquevel M, Gastineau M, Vivien D, Bertoglio J, Zugaza JL, Fischmeister R and Lezoualc'h F. (2003) Crosstalk between Rap1 and Rac regulates secretion of sAPPalpha. Nat. Cell Biol. 5: 633-9 [PMID:12819788]

278. Makarenko IG, Meguid MM and Ugrumov MV. (2002) Distribution of serotonin 5-hydroxytriptamine 1B (5$\mathrm{HT}(1 \mathrm{~B}))$ receptors in the normal rat hypothalamus. Neurosci. Lett. 328: 155-9 [PMID:12133578]

279. Malgouris C, Flamand F and Doble A. (1993) Autoradiographic studies of RP 62203, a potent 5-HT2 receptor antagonist. Pharmacological characterization of [3H]RP 62203 binding in the rat brain. Eur. J. Pharmacol. 233: 37-45 [PMID:8472747]

280. Manrique C, Héry F, Faudon M and François-Bellan AM. (1999) Indirect evidence for an association of 5$\mathrm{HT}$ (1B) binding sites with retinal and geniculate axon terminals in the rat suprachiasmatic nucleus. Synapse 33: 314-23 [PMID:10421712]

281. Manzke T, Guenther U, Ponimaskin EG, Haller M, Dutschmann M, Schwarzacher S and Richter DW. (2003) 5-HT4(a) receptors avert opioid-induced breathing depression without loss of analgesia. Science 301: 226-9 [PMID:12855812]

282. Marazziti D, Ori M, Nardini M, Rossi A, Nardi I and Cassano GB. (2001) mRNA expression of serotonin receptors of type $2 C$ and $5 A$ in human resting lymphocytes. Neuropsychobiology 43: 123-6 [PMID:11287788]

283. Marchetti E, Dumuis A, Bockaert J, Soumireu-Mourat B and Roman FS. (2000) Differential modulation of the 5-HT(4) receptor agonists and antagonist on rat learning and memory. Neuropharmacology 39: 201727 [PMID:10963745]

284. Marin P, Becamel C, Dumuis A and Bockaert J. (2012) 5-HT receptor-associated protein networks: new targets for drug discovery in psychiatric disorders? Curr Drug Targets 13: 28-52 [PMID:21777185]

285. Markstein R, Matsumoto M, Kohler C, Togashi H, Yoshioka M and Hoyer D. (1999) Pharmacological characterisation of $5-\mathrm{HT}$ receptors positively coupled to adenylyl cyclase in the rat hippocampus. Naunyn Schmiedebergs Arch. Pharmacol. 359: 454-9 [PMID:10431755]

286. Maroteaux L, Saudou F, Amlaiky N, Boschert U, Plassat JL and Hen R. (1992) Mouse 5HT1B serotonin receptor: cloning, functional expression, and localization in motor control centers. Proc. Natl. Acad. Sci. U.S.A. 89: 3020-4 [PMID:1557407]

287. Matthes H, Boschert U, Amlaiky N, Grailhe R, Plassat JL, Muscatelli F, Mattei MG and Hen R. (1993) Mouse 5-hydroxytryptamine $5 \mathrm{~A}$ and 5-hydroxytryptamine5B receptors define a new family of serotonin receptors: cloning, functional expression, and chromosomal localization. Mol. Pharmacol. 43: 313-9 [PMID:8450829]

288. Mattsson C, Sonesson C, Sandahl A, Greiner HE, Gassen M, Plaschke J, Leibrock J and Böttcher H. (2005) 2-Alkyl-3-(1,2,3,6-tetrahydropyridin-4-yl)-1H-indoles as novel 5-HT6 receptor agonists. Bioorg. Med. Chem. Lett. 15: 4230-4 [PMID:16055331] 
289. Maura $G$ and Raiteri M. (1986) Cholinergic terminals in rat hippocampus possess 5-HT1B receptors mediating inhibition of acetylcholine release. Eur. J. Pharmacol. 129: 333-7 [PMID:3780847]

290. May JA, Chen HH, Rusinko A, Lynch VM, Sharif NA and McLaughlin MA. (2003) A novel and selective 5HT2 receptor agonist with ocular hypotensive activity: (S)-(+)-1-(2-aminopropyl)-8,9-dihydropyrano[3,2e]indole. J. Med. Chem. 46: 4188-95 [PMID:12954071]

291. McAllister G, Charlesworth A, Snodin C, Beer MS, Noble AJ, Middlemiss DN, Iversen LL and Whiting P. (1992) Molecular cloning of a serotonin receptor from human brain (5HT1E): a fifth $5 \mathrm{HT} 1$-like subtype. Proc. Natl. Acad. Sci. U.S.A. 89: 5517-21 [PMID:1608964]

292. McCall RB, Romero AG, Bienkowski MJ, Harris DW, McGuire JC, Piercey MF, Shuck ME, Smith MW, Svensson KA and Schreur PJ et al.. (1994) Characterization of U-92016A as a selective, orally active, high intrinsic activity 5-hydroxytryptamine1A agonist. J. Pharmacol. Exp. Ther. 271: 875-83 [PMID:7965808]

293. McKinnell RM, Armstrong SR, Beattie DT, Fatheree PR, Long DD, Marquess DG, Shaw JP and Vickery RG. (2013) Discovery of TD-8954, a clinical stage 5-HT(4) receptor agonist with gastrointestinal prokinetic properties. Bioorg. Med. Chem. Lett. 23: 4210-5 [PMID:23756062]

294. McLean PG and Coupar IM. (1996) Stimulation of cyclic AMP formation in the circular smooth muscle of human colon by activation of 5-HT4-like receptors. Br. J. Pharmacol. 117: 238-9 [PMID:8789374]

295. McLean PG and Coupar IM. (1996) Further investigation into the signal transduction mechanism of the 5HT4-like receptor in the circular smooth muscle of human colon. Br. J. Pharmacol. 118: 1058-64 [PMID:8799582]

296. Medhurst AD, Lezoualc'h F, Fischmeister R, Middlemiss DN and Sanger GJ. (2001) Quantitative mRNA analysis of five C-terminal splice variants of the human 5-HT4 receptor in the central nervous system by TaqMan real time RT-PCR. Brain Res. Mol. Brain Res. 90: 125-34 [PMID:11406291]

297. Mialet J, Berque-Bestel I, Eftekhari P, Gastineau M, Giner M, Dahmoune Y, Donzeau-Gouge P, Hoebeke J, Langlois M and Sicsic S et al.. (2000) Isolation of the serotoninergic 5-HT4(e) receptor from human heart and comparative analysis of its pharmacological profile in C6-glial and $\mathrm{CHO}$ cell lines. Br. J. Pharmacol. 129: 771-81 [PMID:10683202]

298. Mialet J, Berque-Bestel I, Sicsic S, Langlois M, Fischmeister R and Lezoualc'h F. (2000) Pharmacological characterization of the human $5-\mathrm{HT}(4(\mathrm{~d}))$ receptor splice variant stably expressed in Chinese hamster ovary cells. Br. J. Pharmacol. 131: 827-35 [PMID:11030734]

299. Mialet J, Dahmoune Y, Lezoualc'h F, Berque-Bestel I, Eftekhari P, Hoebeke J, Sicsic S, Langlois M and Fischmeister R. (2000) Exploration of the ligand binding site of the human 5-HT(4) receptor by sitedirected mutagenesis and molecular modeling. Br. J. Pharmacol. 130: 527-38 [PMID:10821780]

300. Middlemiss DN, Göthert M, Schlicker E, Scott CM, Selkirk JV, Watson J, Gaster LM, Wyman P, Riley G and Price GW. (1999) SB-236057, a selective 5-HT1B receptor inverse agonist, blocks the 5-HT human terminal autoreceptor. Eur. J. Pharmacol. 375: 359-65 [PMID:10443589]

301. Mijnster MJ, Raimundo AG, Koskuba K, Klop H, Docter GJ, Groenewegen HJ and Voorn P. (1997) Regional and cellular distribution of serotonin 5-hydroxytryptamine2a receptor mRNA in the nucleus accumbens, olfactory tubercle, and caudate putamen of the rat. J. Comp. Neurol. 389: 1-11 [PMID:9390756]

302. Millan MJ, Gobert A, Lejeune F, Dekeyne A, Newman-Tancredi A, Pasteau V, Rivet JM and Cussac D. (2003) The novel melatonin agonist agomelatine (S20098) is an antagonist at 5-hydroxytryptamine2C receptors, blockade of which enhances the activity of frontocortical dopaminergic and adrenergic pathways. J. Pharmacol. Exp. Ther. 306: 954-64 [PMID:12750432]

303. Millan MJ, Gobert A, Newman-Tancredi A, Audinot V, Lejeune F, Rivet JM, Cussac D, Nicolas JP, Muller O and Lavielle G. (1998) S 16924 ((R)-2-[1-[2-(2,3-dihydro-benzo[1,4] dioxin-5-Yloxy)-ethyl]-pyrrolidin-3yl]1-(4-fluoro-phenyl)-ethanone), a novel, potential antipsychotic with marked serotonin (5-HT)1A agonist properties: I. Receptorial and neurochemical profile in comparison with clozapine and haloperidol. $J$. Pharmacol. Exp. Ther. 286: 1341-55 [PMID:9732398]

304. Millan MJ, Gobert A, Newman-Tancredi A, Lejeune F, Cussac D, Rivet JM, Audinot V, Dubuffet T and Lavielle G. (2000) S33084, a novel, potent, selective, and competitive antagonist at dopamine D(3)- 
receptors: I. Receptorial, electrophysiological and neurochemical profile compared with GR218,231 and L741,626. J. Pharmacol. Exp. Ther. 293: 1048-62 [PMID:10869410]

305. Millan MJ, Maiofiss L, Cussac D, Audinot V, Boutin JA and Newman-Tancredi A. (2002) Differential actions of antiparkinson agents at multiple classes of monoaminergic receptor. I. A multivariate analysis of the binding profiles of 14 drugs at 21 native and cloned human receptor subtypes. J. Pharmacol. Exp.

Ther. 303: 791-804 [PMID:12388666]

306. Millan MJ, Newman-Tancredi A, Audinot V, Cussac D, Lejeune F, Nicolas JP, Cogé F, Galizzi JP, Boutin JA and Rivet JM et al.. (2000) Agonist and antagonist actions of yohimbine as compared to fluparoxan at alpha(2)-adrenergic receptors (AR)s, serotonin (5-HT)(1A), 5-HT(1B), 5-HT(1D) and dopamine $\mathrm{D}(2)$ and $D(3)$ receptors. Significance for the modulation of frontocortical monoaminergic transmission and depressive states. Synapse 35: 79-95 [PMID:10611634]

307. Miller KJ and Teitler M. (1992) Quantitative autoradiography of 5-CT-sensitive (5-HT1D) and 5-CTinsensitive (5-HT1E) serotonin receptors in human brain. Neurosci. Lett. 136: 223-6 [PMID:1641195]

308. Mitsui R, Ono S, Karaki S and Kuwahara A. (2005) Neural and non-neural mediation of propionateinduced contractile responses in the rat distal colon. Neurogastroenterol. Motil. 17: 585-94 [PMID:16078948]

309. Mlinar B and Corradetti R. (2003) Endogenous 5-HT, released by MDMA through serotonin transporterand secretory vesicle-dependent mechanisms, reduces hippocampal excitatory synaptic transmission by preferential activation of 5-HT1B receptors located on CA1 pyramidal neurons. Eur. J. Neurosci. 18: 155971 [PMID:14511335]

310. Mochizuki D, Yuyama $Y$, Tsujita R, Komaki $H$ and Sagai H. (1992) Cloning and expression of the human 5-HT1B-type receptor gene. Biochem. Biophys. Res. Commun. 185: 517-23 [PMID:1610347]

311. Monsma Jr FJ, Shen Y, Ward RP, Hamblin MW and Sibley DR. (1993) Cloning and expression of a novel serotonin receptor with high affinity for tricyclic psychotropic drugs. Mol. Pharmacol. 43: 320-7 [PMID:7680751]

312. Monti JM and Jantos H. (2004) Effects of the 5-HT1A receptor ligands flesinoxan and WAY 100635 given systemically or microinjected into the laterodorsal tegmental nucleus on REM sleep in the rat. Behav. Brain Res. 151: 159-66 [PMID:15084431]

313. Monti JM and Jantos H. (2003) Differential effects of the 5-HT1A receptor agonist flesinoxan given locally or systemically on REM sleep in the rat. Eur. J. Pharmacol. 478: 121-30 [PMID:14575796]

314. Morikawa H, Manzoni OJ, Crabbe JC and Williams JT. (2000) Regulation of central synaptic transmission by 5-HT(1B) auto- and heteroreceptors. Mol. Pharmacol. 58: 1271-8 [PMID:11093763]

315. Moser PC, Bergis OE, Jegham S, Lochead A, Duconseille E, Terranova JP, Caille D, Berque-Bestel I, Lezoualc'h F and Fischmeister R et al.. (2002) SL65.0155, a novel 5-hydroxytryptamine(4) receptor partial agonist with potent cognition-enhancing properties. J. Pharmacol. Exp. Ther. 302: 731-41 [PMID:12130738]

316. Mota A, Bento A, Peñalva A, Pombo M and Dieguez C. (1995) Role of the serotonin receptor subtype 5HT1D on basal and stimulated growth hormone secretion. J. Clin. Endocrinol. Metab. 80: 1973-7 [PMID:7775648]

317. Moummi C, Yang DC and Gullikson GW. (1992) 5-HT4 receptor activation induces relaxation and associated cAMP generation in rat esophagus. Eur. J. Pharmacol. 216: 47-52 [PMID:1326439]

318. Muraki Y, Yamanaka A, Tsujino N, Kilduff TS, Goto K and Sakurai T. (2004) Serotonergic regulation of the orexin/hypocretin neurons through the 5-HT1A receptor. J. Neurosci. 24: 7159-66 [PMID:15306649]

319. Nagakura Y, Akuzawa S, Miyata K, Kamato T, Suzuki T, Ito H and Yamaguchi T. (1999) Pharmacological properties of a novel gastrointestinal prokinetic benzamide selective for human 5-HT4 receptor versus human 5-HT3 receptor. Pharmacol. Res. 39: 375-82 [PMID:10328995]

320. Nagakura Y, Ito H, Kiso T, Naitoh Y and Miyata K. (1997) The selective 5-hydroxytryptamine (5-HT)4receptor agonist RS67506 enhances lower intestinal propulsion in mice. Jpn. J. Pharmacol. 74: 209-12 [PMID:9243330]

321. Nakhai B, Nielsen DA, Linnoila M and Goldman D. (1995) Two naturally occurring amino acid substitutions 
in the human 5-HT1A receptor: glycine 22 to serine 22 and isoleucine 28 to valine 28 . Biochem. Biophys. Res. Commun. 210: 530-6 [PMID:7755630]

322. Napier C, Stewart M, Melrose H, Hopkins B, McHarg A and Wallis R. (1999) Characterisation of the 5-HT receptor binding profile of eletriptan and kinetics of [3H]eletriptan binding at human 5-HT1B and 5-HT1D receptors. Eur. J. Pharmacol. 368: 259-68 [PMID:10193663]

323. Nebigil CG, Choi DS, Dierich A, Hickel P, Le Meur M, Messaddeq N, Launay JM and Maroteaux L. (2000) Serotonin 2B receptor is required for heart development. Proc. Natl. Acad. Sci. U.S.A. 97: 9508-13 [PMID:10944220]

324. Nebigil CG, Hickel P, Messaddeq N, Vonesch JL, Douchet MP, Monassier L, György K, Matz R, Andriantsitohaina $\mathrm{R}$ and Manivet $\mathrm{P}$ et al.. (2001) Ablation of serotonin 5-HT(2B) receptors in mice leads to abnormal cardiac structure and function. Circulation 103: 2973-9 [PMID:11413089]

325. Nebigil CG, Jaffré F, Messaddeq N, Hickel P, Monassier L, Launay JM and Maroteaux L. (2003) Overexpression of the serotonin 5-HT2B receptor in heart leads to abnormal mitochondrial function and cardiac hypertrophy. Circulation 107: 3223-9 [PMID:12810613]

326. Nelson DL, Lucaites VL, Wainscott DB and Glennon RA. (1999) Comparisons of hallucinogenic phenylisopropylamine binding affinities at cloned human 5-HT2A, - $\mathrm{HT}(2 \mathrm{~B})$ and 5-HT2C receptors. Naunyn Schmiedebergs Arch. Pharmacol. 359: 1-6 [PMID:9933142]

327. Nelson DL, Phebus LA, Johnson KW, Wainscott DB, Cohen ML, Calligaro DO and Xu YC. (2010) Preclinical pharmacological profile of the selective $5-\mathrm{HT} 1 \mathrm{~F}$ receptor agonist lasmiditan. Cephalalgia 30 : 1159-69 [PMID:20855361]

328. Newman-Tancredi A, Audinot V, Moreira C, Verrièle L and Millan MJ. (2000) Inverse agonism and constitutive activity as functional correlates of serotonin h5-HT(1B) receptor/G-protein stoichiometry. Mol. Pharmacol. 58: 1042-9 [PMID:11040052]

329. Newman-Tancredi A, Conte C, Chaput C, Verrièle L, Audinot-Bouchez V, Lochon S, Lavielle G and Millan MJ. (1997) Agonist activity of antimigraine drugs at recombinant human 5-HT1A receptors: potential implications for prophylactic and acute therapy. Naunyn Schmiedebergs Arch. Pharmacol. 355: 682-8 [PMID:9205951]

330. Newman-Tancredi A, Cussac D, Audinot V and Millan MJ. (1999) Actions of roxindole at recombinant human dopamine D2, D3 and D4 and serotonin 5-HT1A, 5-HT1B and 5-HT1D receptors. Naunyn Schmiedebergs Arch. Pharmacol. 359: 447-53 [PMID:10431754]

331. Newman-Tancredi A, Gavaudan S, Conte C, Chaput C, Touzard M, Verrièle L, Audinot V and Millan MJ. (1998) Agonist and antagonist actions of antipsychotic agents at 5-HT1A receptors: a [35S]GTPgammaS binding study. Eur. J. Pharmacol. 355: 245-56 [PMID:9760039]

332. Newman-Tancredi A, Martel JC, Assié MB, Buritova J, Lauressergues E, Cosi C, Heusler P, Bruins Slot L, Colpaert FC and Vacher B et al.. (2009) Signal transduction and functional selectivity of F15599, a preferential post-synaptic 5-HT1A receptor agonist. Br. J. Pharmacol. 156: 338-53 [PMID:19154445]

333. Newman-Tancredi A, Verrièle L, Chaput $C$ and Millan MJ. (1998) Labelling of recombinant human and native rat serotonin 5-HT1A receptors by a novel, selective radioligand, [3H]-S 15535: definition of its binding profile using agonists, antagonists and inverse agonists. Naunyn Schmiedebergs Arch. Pharmacol. 357: 205-17 [PMID:9550290]

334. Newman-Tancredi A, Wootton R and Strange PG. (1992) High-level stable expression of recombinant 5HT1A 5-hydroxytryptamine receptors in Chinese hamster ovary cells. Biochem. J. 285 ( Pt 3): 933-8 [PMID:1386736]

335. Nichols DE, Frescas S, Marona-Lewicka D and Kurrasch-Orbaugh DM. (2002) Lysergamides of isomeric 2,4-dimethylazetidines map the binding orientation of the diethylamide moiety in the potent hallucinogenic agent N,N-diethyllysergamide (LSD). J. Med. Chem. 45: 4344-9 [PMID:12213075]

336. Nilsson T, Longmore J, Shaw D, Olesen IJ and Edvinsson L. (1999) Contractile 5-HT1B receptors in human cerebral arteries: pharmacological characterization and localization with immunocytochemistry. $\mathrm{Br}$. J. Pharmacol. 128: 1133-40 [PMID:10578124]

337. Nilsson T, Longmore J, Shaw D, Pantev E, Bard JA, Branchek T and Edvinsson L. (1999) Characterisation 
of 5-HT receptors in human coronary arteries by molecular and pharmacological techniques. Eur. J. Pharmacol. 372: 49-56 [PMID:10374714]

338. Ning Y, Zhu JX and Chan HC. (2004) Regulation of ion transport by 5-hydroxytryptamine in rat colon.Clin. Exp. Pharmacol. Physiol. 31: 424-8 [PMID:15236628]

339. Niswender CM, Copeland SC, Herrick-Davis K, Emeson RB and Sanders-Bush E. (1999) RNA editing of the human serotonin 5-hydroxytryptamine $2 \mathrm{C}$ receptor silences constitutive activity. J. Biol. Chem. 274: 9472-8 [PMID:10092629]

340. Noda M, Higashida H, Aoki S and Wada K. (2004) Multiple signal transduction pathways mediated by 5HT receptors. Mol. Neurobiol. 29: 31-9 [PMID:15034221]

341. Noda M, Yasuda S, Okada M, Higashida H, Shimada A, Iwata N, Ozaki N, Nishikawa K, Shirasawa S and Uchida M et al.. (2003) Recombinant human serotonin 5A receptors stably expressed in C6 glioma cells couple to multiple signal transduction pathways. J. Neurochem. 84: 222-32 [PMID:12558985]

342. Nonogaki K, Abdallah L, Goulding EH, Bonasera SJ and Tecott LH. (2003) Hyperactivity and reduced energy cost of physical activity in serotonin $5-\mathrm{HT}(2 \mathrm{C})$ receptor mutant mice. Diabetes 52: 315-20 [PMID:12540602]

343. Nonogaki K, Memon RA, Grunfeld C, Feingold KR and Tecott LH. (2002) Altered gene expressions involved in energy expenditure in 5-HT(2C) receptor mutant mice. Biochem. Biophys. Res. Commun. 295: 249-54 [PMID:12150939]

344. Norum JH, Hart K and Levy FO. (2003) Ras-dependent ERK activation by the human G(s)-coupled serotonin receptors 5-HT4(b) and 5-HT7(a). J. Biol. Chem. 278: 3098-104 [PMID:12446729]

345. Ochi T, Sakamoto M, Minamida A, Suzuki K, Ueda T, Une T, Toda H, Matsumoto K and Terauchi Y. (2005) Syntheses and properties of the major hydroxy metabolites in humans of blonanserin AD-5423, a novel antipsychotic agent. Bioorg. Med. Chem. Lett. 15: 1055-9 [PMID:15686911]

346. Okamoto K, Imbe H, Morikawa Y, Itoh M, Sekimoto M, Nemoto K and Senba E. (2002) 5-HT2A receptor subtype in the peripheral branch of sensory fibers is involved in the potentiation of inflammatory pain in rats. Pain 99: 133-43 [PMID:12237191]

347. Olsen MA, Nawoschik SP, Schurman BR, Schmitt HL, Burno M, Smith DL and Schechter LE. (1999) Identification of a human 5-HT6 receptor variant produced by alternative splicing. Brain Res Mol Brain Res 64: 255-263 [PMID:9931499]

348. Ono S, Mitsui R, Karaki S and Kuwahara A. (2005) Muscarinic and 5-HT4 receptors participate in the regulation of the frequency of spontaneous contractions of the longitudinal muscle in rat distal colon. Biomed. Res. 26: 173-7 [PMID:16152733]

349. Osei-Owusu P, James A, Crane J and Scrogin KE. (2005) 5-Hydroxytryptamine $1 \mathrm{~A}$ receptors in the paraventricular nucleus of the hypothalamus mediate oxytocin and adrenocorticotropin hormone release and some behavioral components of the serotonin syndrome. J. Pharmacol. Exp. Ther. 313: 1324-30 [PMID:15743927]

350. Ouadid H, Seguin J, Dumuis A, Bockaert J and Nargeot J. (1992) Serotonin increases calcium current in human atrial myocytes via the newly described 5-hydroxytryptamine4 receptors. Mol. Pharmacol. 41: 34651 [PMID:1311410]

351. Palacios JM, Pazos A and Hoyer D. (2017) A short history of the $5-\mathrm{H}_{2 \mathrm{C}}$ receptor: from the choroid plexus to depression, obesity and addiction treatment. Psychopharmacology (Berl.) 234: 1395-1418 [PMID:28265714]

352. Parker CA, Gunn RN, Rabiner EA, Slifstein M, Comley R, Salinas C, Johnson CN, Jakobsen S, Houle S and Laruelle $M$ et al.. (2012) Radiosynthesis and characterization of 11C-GSK215083 as a PET radioligand for the 5-HT6 receptor. J. Nucl. Med. 53: 295-303 [PMID:22223878]

353. Parker EM, Izzarelli DG, Lewis-Higgins L, Palmer D and Shapiro RA. (1996) Two amino acid differences in the sixth transmembrane domain are partially responsible for the pharmacological differences between the 5-HT1D beta and 5-HT1E 5-hydroxytryptamine receptors. J. Neurochem. 67: 2096-103 [PMID:8863519]

354. Parker MA, Marona-Lewicka D, Lucaites VL, Nelson DL and Nichols DE. (1998) A novel (benzodifuranyl)aminoalkane with extremely potent activity at the 5-HT2A receptor. J. Med. Chem. 41: 
5148-9 [PMID:9857084]

355. Parks CL, Robinson PS, Sibille E, Shenk T and Toth M. (1998) Increased anxiety of mice lacking the serotonin1A receptor. Proc. Natl. Acad. Sci. U.S.A. 95: 10734-9 [PMID:9724773]

356. Pasqualetti M, Ori M, Nardi I, Castagna M, Cassano GB and Marazziti D. (1998) Distribution of the 5-HT5A serotonin receptor mRNA in the human brain. Brain Res. Mol. Brain Res. 56: 1-8 [PMID:9602024]

357. Pattij T, Broersen LM, van der Linde J, Groenink L, van der Gugten J, Maes RA and Olivier B. (2003) Operant learning and differential-reinforcement-of-low-rate 36-s responding in 5-HT1A and 5-HT1B receptor knockout mice. Behav. Brain Res. 141: 137-45 [PMID:12742250]

358. Pauwels PJ, Wurch T, Amoureux MC, Palmier C and Colpaert FC. (1996) Stimulation of cloned human serotonin 5-HT1D beta receptor sites in stably transfected $\mathrm{C} 6$ glial cells promotes cell growth. $J$. Neurochem. 66: 65-73 [PMID:8522991]

359. Pazos A, Hoyer D and Palacios JM. (1984) The binding of serotonergic ligands to the porcine choroid plexus: characterization of a new type of serotonin recognition site. Eur. J. Pharmacol. 106: 539-46 [PMID:6519175]

360. Peng Y, McCorvy JD, Harpsøe K, Lansu K, Yuan S, Popov P, Qu L, Pu M, Che T and Nikolajsen LFet al.. (2018) $5-\mathrm{HT}_{2 \mathrm{C}}$ Receptor Structures Reveal the Structural Basis of GPCR Polypharmacology.Cell 172: 719-730.e14 [PMID:29398112]

361. Perez-Garcia GS and Meneses A. (2005) Effects of the potential 5-HT7 receptor agonist AS 19 in an autoshaping learning task. Behav Brain Res 163: 136-140 [PMID:15936093]

362. Perez-García G and Meneses A. (2005) Oral administration of the 5-HT6 receptor antagonists SB-357134 and SB-399885 improves memory formation in an autoshaping learning task. Pharmacol. Biochem. Behav. 81: 673-82 [PMID:15964617]

363. Pesonen U, Rouru J, Huupponen R and Koulu M. (1991) Effects of repeated administration of mifepristone and 8-OH-DPAT on expression of preproneuropeptide $\mathrm{Y}$ mRNA in the arcuate nucleus of obese Zucker rats. Brain Res. Mol. Brain Res. 10: 267-72 [PMID:1653393]

364. Phebus LA, Johnson KW, Zgombick JM, Gilbert PJ, Van Belle K, Mancuso V, Nelson DL, Calligaro DO, Kiefer Jr AD and Branchek TA et al.. (1997) Characterization of LY344864 as a pharmacological tool to study 5-HT1F receptors: binding affinities, brain penetration and activity in the neurogenic dural inflammation model of migraine. Life Sci. 61: 2117-26 [PMID:9395253]

365. Pickard GE, Smith BN, Belenky M, Rea MA, Dudek FE and Sollars PJ. (1999) 5-HT1B receptor-mediated presynaptic inhibition of retinal input to the suprachiasmatic nucleus. J. Neurosci. 19: 4034-45 [PMID:10234032]

366. Pierce PA, Xie GX, Levine JD and Peroutka SJ. (1996) 5-Hydroxytryptamine receptor subtype messenger RNAs in rat peripheral sensory and sympathetic ganglia: a polymerase chain reaction study. Neuroscience 70: 553-9 [PMID:8848158]

367. Pierce PA, Xie GX, Peroutka SJ, Green PG and Levine JD. (1995) 5-Hydroxytryptamine-induced synovial plasma extravasation is mediated via 5 -hydroxytryptamine2A receptors on sympathetic efferent terminals. J. Pharmacol. Exp. Ther. 275: 502-8 [PMID:7562592]

368. Pindon A, van Hecke G, van Gompel P, Lesage AS, Leysen JE and Jurzak M. (2002) Differences in signal transduction of two 5-HT4 receptor splice variants: compound specificity and dual coupling with Galphasand Galphai/o-proteins. Mol. Pharmacol. 61: 85-96 [PMID:11752209]

369. Piñeyro G, de Montigny $C$ and Blier P. (1995) 5-HT1D receptors regulate 5-HT release in the rat raphe nuclei. In vivo voltammetry and in vitro superfusion studies. Neuropsychopharmacology 13: 249-60 [PMID:8602897]

370. Plassat JL, Amlaiky N and Hen R. (1993) Molecular cloning of a mammalian serotonin receptor that activates adenylate cyclase. Mol. Pharmacol. 44: 229-36 [PMID:8394987]

371. Pompeiano M, Palacios JM and Mengod G. (1992) Distribution and cellular localization of mRNA coding for 5-HT1A receptor in the rat brain: correlation with receptor binding. J. Neurosci. 12: 440-53 [PMID:1531498]

372. Pompeiano M, Palacios JM and Mengod G. (1994) Distribution of the serotonin 5-HT2 receptor family 
mRNAs: comparison between 5-HT2A and 5-HT2C receptors. Brain Res. Mol. Brain Res. 23: 163-78 [PMID:8028479]

373. Ponimaskin EG, Profirovic J, Vaiskunaite R, Richter DW and Voyno-Yasenetskaya TA. (2002) 5Hydroxytryptamine 4(a) receptor is coupled to the Galpha subunit of heterotrimeric G13 protein. J. Biol. Chem. 277: 20812-9 [PMID:11923294]

374. Popova NK, Naumenko VS, Plyusnina IZ and Kulikov AV. (2005) Reduction in 5-HT1A receptor density, 5HT1A mRNA expression, and functional correlates for $5-\mathrm{HT} 1 \mathrm{~A}$ receptors in genetically defined aggressive rats. J. Neurosci. Res. 80: 286-92 [PMID:15765530]

375. Porter RH, Benwell KR, Lamb H, Malcolm CS, Allen NH, Revell DF, Adams DR and Sheardown MJ. (1999) Functional characterization of agonists at recombinant human 5-HT2A, 5-HT2B and 5-HT2C receptors in CHO-K1 cells. Br. J. Pharmacol. 128: 13-20 [PMID:10498829]

376. Potrebic S, Ahn AH, Skinner K, Fields HL and Basbaum Al. (2003) Peptidergic nociceptors of both trigeminal and dorsal root ganglia express serotonin 1D receptors: implications for the selective antimigraine action of triptans. J. Neurosci. 23: 10988-97 [PMID:14645495]

377. Price GW, Burton MJ, Collin LJ, Duckworth M, Gaster L, Göthert M, Jones BJ, Roberts C, Watson JM and Middlemiss DN. (1997) SB-216641 and BRL-15572--compounds to pharmacologically discriminate h5HT1B and h5-HT1D receptors. Naunyn Schmiedebergs Arch. Pharmacol. 356: 312-20 [PMID:9303567]

378. Price RD, Weiner DM, Chang MS and Sanders-Bush E. (2001) RNA editing of the human serotonin 5HT2C receptor alters receptor-mediated activation of G13 protein. J. Biol. Chem. 276: 44663-8 [PMID:11572865]

379. Purohit A, Smith C, Herrick-Davis K and Teitler M. (2005) Stable expression of constitutively activated mutant h5HT6 and h5HT7 serotonin receptors: inverse agonist activity of antipsychotic drugs. Psychopharmacology (Berl.) 179: 461-9 [PMID:15821958]

380. Pälvimäki EP, Roth BL, Majasuo H, Laakso A, Kuoppamäki M, Syvälahti E and Hietala J. (1996) Interactions of selective serotonin reuptake inhibitors with the serotonin 5-HT2c receptor. Psychopharmacology (Berl.) 126: 234-40 [PMID:8876023]

381. Quist JF, Barr CL, Schachar R, Roberts W, Malone M, Tannock R, Basile VS, Beitchman J and Kennedy JL. (2003) The serotonin 5-HT1B receptor gene and attention deficit hyperactivity disorder. Mol. Psychiatry 8: 98-102 [PMID:12556913]

382. Ramage AG and Villalón CM. (2008) 5-hydroxytryptamine and cardiovascular regulation. Trends Pharmacol. Sci. 29: 472-81 [PMID:19086344]

383. Ramboz S, Oosting R, Amara DA, Kung HF, Blier P, Mendelsohn M, Mann JJ, Brunner D and Hen R. (1998) Serotonin receptor 1 A knockout: an animal model of anxiety-related disorder. Proc. Natl. Acad. Sci. U.S.A. 95: 14476-81 [PMID:9826725]

384. Ramirez MJ, García-Garayoa E, Romero G, Monge A, Roca J, Del Río J and Lasheras B. (1997) VB20B7, a novel 5-HT-ergic agent with gastrokinetic activity. I. Interaction with 5-HT3 and 5-HT4 receptors. $J$. Pharm. Pharmacol. 49: 58-65 [PMID:9120772]

385. Rashid M, Manivet P, Nishio H, Pratuangdejkul J, Rajab M, Ishiguro M, Launay JM and Nagatomo T. (2003) Identification of the binding sites and selectivity of sarpogrelate, a novel 5-HT2 antagonist, to human 5-HT2A, 5-HT2B and 5-HT2C receptor subtypes by molecular modeling. Life Sci. 73: 193-207 [PMID:12738034]

386. Rauser L, Savage JE, Meltzer HY and Roth BL. (2001) Inverse agonist actions of typical and atypical antipsychotic drugs at the human 5-hydroxytryptamine(2C) receptor. J. Pharmacol. Exp. Ther. 299: 83-9 [PMID:11561066]

387. Raymond JR, Kim J, Beach RE and Tisher CC. (1993) Immunohistochemical mapping of cellular and subcellular distribution of 5-HT1A receptors in rat and human kidneys. Am. J. Physiol. 264: F9-19 [PMID:8430834]

388. Reavill C, Kettle A, Holland V, Riley G and Blackburn TP. (1999) Attenuation of haloperidol-induced catalepsy by a 5-HT2C receptor antagonist. Br. J. Pharmacol. 126: 572-4 [PMID:10188965]

389. Reavill C, Taylor SG, Wood MD, Ashmeade T, Austin NE, Avenell KY, Boyfield I, Branch CL, Cilia J and 
Coldwell MC et al.. (2000) Pharmacological actions of a novel, high-affinity, and selective human dopamine D(3) receptor antagonist, SB-277011-A. J. Pharmacol. Exp. Ther. 294: 1154-65 [PMID:10945872]

390. Rees S, den Daas I, Foord S, Goodson S, Bull D, Kilpatrick G and Lee M. (1994) Cloning and characterisation of the human 5-HT5A serotonin receptor. FEBS Lett. 355: 242-6 [PMID:7988681]

391. Reeves JJ, Bunce KT and Humphrey PP. (1991) Investigation into the 5-hydroxytryptamine receptor mediating smooth muscle relaxation in the rat oesophagus. Br. J. Pharmacol. 103: 1067-72 [PMID:1878746]

392. Reynolds GP, Mason SL, Meldrum A, De Keczer S, Parnes H, Eglen RM and Wong EH. (1995) 5Hydroxytryptamine (5-HT)4 receptors in post mortem human brain tissue: distribution, pharmacology and effects of neurodegenerative diseases. Br. J. Pharmacol. 114: 993-8 [PMID:7780656]

393. Rivail L, Giner M, Gastineau M, Berthouze M, Soulier JL, Fischmeister R, Lezoualc'h F, Maigret B, Sicsic S and Berque-Bestel I. (2004) New insights into the human 5-HT4 receptor binding site: exploration of a hydrophobic pocket. Br. J. Pharmacol. 143: 361-70 [PMID:15351779]

394. Rocha-González HI, Meneses A, Carlton SM and Granados-Soto V. (2005) Pronociceptive role of peripheral and spinal 5-HT7 receptors in the formalin test. Pain 117: 182-92 [PMID:16098671]

395. Rogers DC and Hagan JJ. (2001) 5-HT6 receptor antagonists enhance retention of a water maze task in the rat. Psychopharmacology (Berl.) 158: 114-9 [PMID:11702084]

396. Rosier A, Dupont P, Peuskens J, Bormans G, Vandenberghe R, Maes M, de Groot T, Schiepers C, Verbruggen A and Mortelmans L. (1996) Visualisation of loss of 5-HT2A receptors with age in healthy volunteers using [18F]altanserin and positron emission tomographic imaging. Psychiatry Res 68: 11-22 [PMID:9027929]

397. Roth BL, Craigo SC, Choudhary MS, Uluer A, Monsma Jr FJ, Shen Y, Meltzer HY and Sibley DR. (1994) Binding of typical and atypical antipsychotic agents to 5-hydroxytryptamine-6 and 5-hydroxytryptamine-7 receptors. J. Pharmacol. Exp. Ther. 268: 1403-10 [PMID:7908055]

398. Roth BL, Ernsberger P, Steinberg SA, Rao S, Rauser L, Savage J, Hufeisen S, Berridge MS and Muzic Jr RF. (2001) The in vitro pharmacology of the beta-adrenergic receptor pet ligand (s)-fluorocarazolol reveals high affinity for cloned beta-adrenergic receptors and moderate affinity for the human 5-HT1A receptor. Psychopharmacology (Berl.) 157: 111-4 [PMID:11512051]

399. Rothman RB, Baumann MH, Savage JE, Rauser L, McBride A, Hufeisen SJ and Roth BL. (2000) Evidence for possible involvement of 5-HT(2B) receptors in the cardiac valvulopathy associated with fenfluramine and other serotonergic medications. Circulation 102: 2836-41 [PMID:11104741]

400. Rousselle JC, Plantefol M, Fillion MP, Massot O, Pauwels PJ and Fillion G. (1998) Specific interaction of 5$\mathrm{HT}$-moduline with human $5-\mathrm{HT} 1 \mathrm{~b}$ as well as $5-\mathrm{HT} 1 \mathrm{~d}$ receptors expressed in transfected cultured cells. Naunyn Schmiedebergs Arch. Pharmacol. 358: 279-86 [PMID:9774213]

401. Ruat M, Traiffort E, Arrang JM, Tardivel-Lacombe J, Diaz J, Leurs R and Schwartz JC. (1993) A novel rat serotonin (5-HT6) receptor: molecular cloning, localization and stimulation of cAMP accumulation. Biochem. Biophys. Res. Commun. 193: 268-76 [PMID:8389146]

402. Ruat M, Traiffort E, Leurs R, Tardivel-Lacombe J, Diaz J, Arrang JM and Schwartz JC. (1993) Molecular cloning, characterization, and localization of a high-affinity serotonin receptor (5-HT7) activating cAMP formation. Proc. Natl. Acad. Sci. U.S.A. 90: 8547-51 [PMID:8397408]

403. Russell MG, Matassa VG, Pengilley RR, van Niel MB, Sohal B, Watt AP, Hitzel L, Beer MS, Stanton JA and Broughton HB et al.. (1999) 3-[3-(Piperidin-1-yl)propyl]indoles as highly selective h5-HT(1D) receptor agonists. J. Med. Chem. 42: 4981-5001 [PMID:10585208]

404. Sakurai-Yamashita Y, Takada K, Takemura K, Yamashita K, Enjoji A, Kanematsu T and Taniyama K. (1999) Ability of mosapride to bind to 5-HT4 receptor in the human stomach. Jpn. J. Pharmacol. 79: 493-6 [PMID:10361891]

405. Sakurai-Yamashita Y, Yamashita K, Kanematsu T and Taniyama K. (1999) Localization of the 5-HT(4) receptor in the human and the guinea pig colon. Eur J Pharmaco/383: 281-285 [PMID:10594320]

406. Sakurai-Yamashita Y, Yamashita K, Yoshimura M and Taniyama K. (2000) Differential localization of 5hydroxytryptamine3 and 5-hydroxytryptamine4 receptors in the human rectum. Life Sci. 66: 31-4 
[PMID:10658921]

407. Sari Y, Miquel MC, Brisorgueil MJ, Ruiz G, Doucet E, Hamon M and Vergé D. (1999) Cellular and subcellular localization of 5-hydroxytryptamine1B receptors in the rat central nervous system: immunocytochemical, autoradiographic and lesion studies. Neuroscience 88: 899-915 [PMID:10363826]

408. Sarnyai Z, Sibille EL, Pavlides C, Fenster RJ, McEwen BS and Toth M. (2000) Impaired hippocampaldependent learning and functional abnormalities in the hippocampus in mice lacking serotonin $(1 \mathrm{~A})$ receptors. Proc. Natl. Acad. Sci. U.S.A. 97: 14731-6 [PMID:11121072]

409. Saudou F, Amara DA, Dierich A, LeMeur M, Ramboz S, Segu L, Buhot MC and Hen R. (1994) Enhanced aggressive behavior in mice lacking 5-HT1B receptor. Science 265: 1875-8 [PMID:8091214]

410. Schaerlinger B, Hickel P, Etienne N, Guesnier L and Maroteaux L. (2003) Agonist actions of dihydroergotamine at $5-\mathrm{HT} 2 \mathrm{~B}$ and $5-\mathrm{HT} 2 \mathrm{C}$ receptors and their possible relevance to antimigraine efficacy. Br. J. Pharmacol. 140: 277-84 [PMID:12970106]

411. Schechter LE, Lin Q, Smith DL, Zhang G, Shan Q, Platt B, Brandt MR, Dawson LA, Cole D and Bernotas R et al.. (2008) Neuropharmacological profile of novel and selective 5-HT6 receptor agonists: WAY-181187 and WAY-208466. Neuropsychopharmacology 33: 1323-35 [PMID:17625499]

412. Schmitz B, Ullmer C, Segelcke D, Gwarek M, Zhu XR and Lübbert H. (2015) BF-1--a novel selective 5HT2B receptor antagonist blocking neurogenic dural plasma protein extravasation in guinea pigs. Eur. J. Pharmacol. 751: 73-80 [PMID:25666387]

413. Schmuck K, Ullmer C, Engels $P$ and Lübbert $H$. (1994) Cloning and functional characterization of the human 5-HT2B serotonin receptor. FEBS Lett. 342: 85-90 [PMID:8143856]

414. Schotte A, Janssen PF, Gommeren W, Luyten WH, Van Gompel P, Lesage AS, De Loore K and Leysen JE. (1996) Risperidone compared with new and reference antipsychotic drugs: in vitro and in vivo receptor binding. Psychopharmacology (Berl.) 124: 57-73 [PMID:8935801]

415. Seeman $\mathrm{P}$, Chau-Wong M, Tedesco J and Wong K. (1975) Brain receptors for antipsychotic drugs and dopamine: direct binding assays. Proc. Natl. Acad. Sci. U.S.A. 72: 4376-80 [PMID:1060115]

416. Selkirk JV, Scott C, Ho M, Burton MJ, Watson J, Gaster LM, Collin L, Jones BJ, Middlemiss DN and Price GW. (1998) SB-224289--a novel selective (human) 5-HT1B receptor antagonist with negative intrinsic activity. Br. J. Pharmacol. 125: 202-8 [PMID:9776361]

417. Seo HJ, Park EJ, Kim MJ, Kang SY, Lee SH, Kim HJ, Lee KN, Jung ME, Lee M and Kim MSet al.. (2011) Design and synthesis of novel arylpiperazine derivatives containing the imidazole core targeting $5-\mathrm{HT}(2 \mathrm{~A})$ receptor and 5-HT transporter. J. Med. Chem. 54: 6305-18 [PMID:21823597]

418. Serrats J, Mengod G and Cortés R. (2005) Expression of serotonin 5-HT2C receptors in GABAergic cells of the anterior raphe nuclei. J. Chem. Neuroanat. 29: 83-91 [PMID:15652696]

419. Shahid M, Walker GB, Zorn SH and Wong EH. (2009) Asenapine: a novel psychopharmacologic agent with a unique human receptor signature. J. Psychopharmacol. (Oxford) 23: 65-73 [PMID:18308814]

420. Shajib MS and Khan WI. (2015) The role of serotonin and its receptors in activation of immune responses and inflammation. Acta Physiol (Oxf) 213: 561-74 [PMID:25439045]

421. Shannon HE and Lutz EA. (2000) Yohimbine produces antinociception in the formalin test in rats: involvement of serotonin(1A) receptors. Psychopharmacology (Berl.) 149: 93-7 [PMID:10789888]

422. Shapiro DA, Kristiansen K, Kroeze WK and Roth BL. (2000) Differential modes of agonist binding to 5hydroxytryptamine $(2 \mathrm{~A})$ serotonin receptors revealed by mutation and molecular modeling of conserved residues in transmembrane region 5. Mol. Pharmacol. 58: 877-86 [PMID:11040033]

423. Shapiro DA, Renock S, Arrington E, Chiodo LA, Liu LX, Sibley DR, Roth BL and Mailman R. (2003) Aripiprazole, a novel atypical antipsychotic drug with a unique and robust pharmacology.

Neuropsychopharmacology 28: 1400-11 [PMID:12784105]

424. Shen Y, Monsma Jr FJ, Metcalf MA, Jose PA, Hamblin MW and Sibley DR. (1993) Molecular cloning and expression of a 5-hydroxytryptamine7 serotonin receptor subtype. J. Biol. Chem. 268: 18200-4 [PMID:8394362]

425. Shimron-Abarbanell D, Nöthen MM, Erdmann J and Propping P. (1995) Lack of genetically determined structural variants of the human serotonin-1E $(5-\mathrm{HT} 1 \mathrm{E})$ receptor protein points to its evolutionary 
conservation. Brain Res. Mol. Brain Res. 29: 387-90 [PMID:7609628]

426. Shippenberg TS, Hen R and He M. (2000) Region-specific enhancement of basal extracellular and cocaine-evoked dopamine levels following constitutive deletion of the Serotonin(1B) receptor. J. Neurochem. 75: 258-65 [PMID:10854269]

427. Siddiqui A, Abu-Amara M, Aldairy C, Hagan JJ and Wilson C. (2004) 5-HT7 receptor subtype as a mediator of the serotonergic regulation of luteinizing hormone release in the zona incerta. Eur. J. Pharmacol. 491: 77-84 [PMID:15102536]

428. Singer JH, Bellingham MC and Berger AJ. (1996) Presynaptic inhibition of glutamatergic synaptic transmission to rat motoneurons by serotonin. J. Neurophysiol. 76: 799-807 [PMID:8871200]

429. Sleight AJ, Boess FG, Bös M, Levet-Trafit B, Riemer C and Bourson A. (1998) Characterization of Ro 046790 and Ro 63-0563: potent and selective antagonists at human and rat 5-HT6 receptors. Br. J. Pharmacol. 124: 556-62 [PMID:9647481]

430. Sleight AJ, Stam NJ, Mutel V and Vanderheyden PM. (1996) Radiolabelling of the human 5-HT2A receptor with an agonist, a partial agonist and an antagonist: effects on apparent agonist affinities. Biochem. Pharmacol. 51: 71-6 [PMID:8534270]

431. Smith B and Smith J. (2005) 5HT2C receptor modulators. Patent number: US6953787 B2.

432. Smith JA, Beattie DT, Marquess D, Shaw JP, Vickery RG and Humphrey PP. (2008) The in vitro pharmacological profile of TD-5108, a selective 5-HT(4) receptor agonist with high intrinsic activity. Naunyn Schmiedebergs Arch. Pharmacol. 378: 125-37 [PMID:18415081]

433. Snyder GL, Vanover KE, Zhu H, Miller DB, O'Callaghan JP, Tomesch J, Li P, Zhang Q, Krishnan V and Hendrick JP et al.. (2015) Functional profile of a novel modulator of serotonin, dopamine, and glutamate neurotransmission. Psychopharmacology (Berl.) 232: 605-21 [PMID:25120104]

434. Soyka M, Preuss UW, Koller G, Zill P and Bondy B. (2004) Association of 5-HT1B receptor gene and antisocial behavior in alcoholism. J Neural Transm (Vienna) 111: 101-9 [PMID:14714219]

435. Spedding M, Newman-Tancredi A, Millan MJ, Dacquet C, Michel AN, Jacoby E, Vickery B and Tallentire D. (1998) Interaction of the anxiogenic agent, RS-30199, with 5-HT1A receptors: modulation of sexual activity in the male rat. Neuropharmacology 37: 769-80 [PMID:9707291]

436. Sprouse J, Reynolds L, Braselton J and Schmidt A. (2004) Serotonin-induced phase advances of SCN neuronal firing in vitro: a possible role for 5-HT5A receptors? Synapse 54: 111-8 [PMID:15352136]

437. Sprouse J, Reynolds L, Li X, Braselton J and Schmidt A. (2004) 8-OH-DPAT as a 5-HT7 agonist: phase shifts of the circadian biological clock through increases in cAMP production. Neuropharmacology 46: 5262 [PMID:14654097]

438. Stam NJ, Roesink C, Dijcks F, Garritsen A, van Herpen A and Olijve W. (1997) Human serotonin 5-HT7 receptor: cloning and pharmacological characterisation of two receptor variants. FEBS Lett. 413: 489-94 [PMID:9303561]

439. Stam NJ, Van Huizen F, Van Alebeek C, Brands J, Dijkema R, Tonnaer JA and Olijve W. (1992) Genomic organization, coding sequence and functional expression of human $5-\mathrm{HT} 2$ and $5-\mathrm{HT} 1 \mathrm{~A}$ receptor genes. Eur. J. Pharmacol. 227: 153-62 [PMID:1330647]

440. Stam NJ, Vanderheyden P, van Alebeek C, Klomp J, de Boer T, van Delft AM and Olijve W. (1994) Genomic organisation and functional expression of the gene encoding the human serotonin 5-HT2C receptor. Eur. J. Pharmacol. 269: 339-48 [PMID:7895773]

441. Stefulj J, Jernej B, Cicin-Sain L, Rinner I and Schauenstein K. (2000) mRNA expression of serotonin receptors in cells of the immune tissues of the rat. Brain Behav. Immun. 14: 219-24 [PMID:10970681]

442. Sánchez $C$ and Hyttel J. (1999) Comparison of the effects of antidepressants and their metabolites on reuptake of biogenic amines and on receptor binding. Cell. Mol. Neurobiol. 19: 467-89 [PMID:10379421]

443. Takeda H, Tsuji M, Ikoshi H, Yamada T, Masuya J, limori M and Matsumiya T. (2005) Effects of a 5-HT7 receptor antagonist DR4004 on the exploratory behavior in a novel environment and on brain monoamine dynamics in mice. Eur. J. Pharmacol. 518: 30-9 [PMID:16002064]

444. Terrón JA. (1997) Role of 5-ht7 receptors in the long-lasting hypotensive response induced by 5hydroxytryptamine in the rat. Br. J. Pharmacol. 121: 563-71 [PMID:9179401] 
445. Terrón JA, Bouchelet I and Hamel E. (2001) 5-HT7 receptor mRNA expression in human trigeminal ganglia. Neurosci. Lett. 302: 9-12 [PMID:11278099]

446. Thomas DR, Atkinson PJ, Ho M, Bromidge SM, Lovell PJ, Villani AJ, Hagan JJ, Middlemiss DN and Price GW. (2000) [(3)H]-SB-269970--A selective antagonist radioligand for 5-HT(7) receptors. Br. J. Pharmacol. 130: 409-17 [PMID:10807680]

447. Thomas DR, Gittins SA, Collin LL, Middlemiss DN, Riley G, Hagan J, Gloger I, Ellis CE, Forbes IT and Brown AM. (1998) Functional characterisation of the human cloned 5-HT7 receptor (long form); antagonist profile of SB-258719. Br. J. Pharmacol. 124: 1300-6 [PMID:9720804]

448. Thomas DR, Melotto S, Massagrande M, Gribble AD, Jeffrey P, Stevens AJ, Deeks NJ, Eddershaw PJ, Fenwick SH and Riley G et al.. (2003) SB-656104-A, a novel selective 5-HT7 receptor antagonist, modulates REM sleep in rats. Br. J. Pharmacol. 139: 705-14 [PMID:12812993]

449. Thomsen WJ, Grottick AJ, Menzaghi F, Reyes-Saldana H, Espitia S, Yuskin D, Whelan K, Martin M, Morgan $\mathrm{M}$ and Chen W et al.. (2008) Lorcaserin, a novel selective human 5-hydroxytryptamine2C agonist: in vitro and in vivo pharmacological characterization. J. Pharmacol. Exp. Ther. 325: 577-87 [PMID:18252809]

450. Torres GE, Holt IL and Andrade R. (1994) Antagonists of 5-HT4 receptor-mediated responses in adult hippocampal neurons. J. Pharmacol. Exp. Ther. 271: 255-61 [PMID:7965722]

451. Trillat AC, Malagié I, Scearce K, Pons D, Anmella MC, Jacquot C, Hen R and Gardier AM. (1997) Regulation of serotonin release in the frontal cortex and ventral hippocampus of homozygous mice lacking 5-HT1B receptors: in vivo microdialysis studies. J. Neurochem. 69: 2019-25 [PMID:9349547]

452. Tuladhar BR, Costall B and Naylor RJ. (1996) Pharmacological characterization of the 5hydroxytryptamine receptor mediating relaxation in the rat isolated ileum. Br. J. Pharmacol. 119: 303-10 [PMID:8886413]

453. Tuo BG, Sellers Z, Paulus P, Barrett KE and Isenberg JI. (2004) 5-HT induces duodenal mucosal bicarbonate secretion via cAMP- and Ca2+-dependent signaling pathways and 5-HT4 receptors in mice. Am. J. Physiol. Gastrointest. Liver Physiol. 286: G444-51 [PMID:14576083]

454. Turner MR, Rabiner EA, Hammers A, Al-Chalabi A, Grasby PM, Shaw CE, Brooks DJ and Leigh PN. (2005) [11C]-WAY100635 PET demonstrates marked 5-HT1A receptor changes in sporadic ALS. Brain 128: 896-905 [PMID:15689356]

455. Van den Wyngaert I, Gommeren W, Verhasselt P, Jurzak M, Leysen J, Luyten W and Bender E. (1997) Cloning and expression of a human serotonin 5-HT4 receptor cDNA. J. Neurochem. 69: 1810-9 [PMID:9349523]

456. Vanover KE, Harvey SC, Son T, Bradley SR, Kold H, Makhay M, Veinbergs I, Spalding TA, Weiner DM and Andersson CM et al.. (2004) Pharmacological characterization of AC-90179 [2-(4-methoxyphenyl)-N(4-methyl-benzyl)-N-(1-methyl-piperidin-4-yl)-acetamide hydrochloride]: a selective serotonin $2 \mathrm{~A}$ receptor inverse agonist. J. Pharmacol. Exp. Ther. 310: 943-51 [PMID:15102927]

457. Varnäs K, Hall H, Bonaventure P and Sedvall G. (2001) Autoradiographic mapping of 5-HT(1B) and 5$\mathrm{HT}(1 \mathrm{D})$ receptors in the post mortem human brain using [(3)H]GR 125743. Brain Res. 915: 47-57 [PMID:11578619]

458. Varnäs K, Hurd YL and Hall H. (2005) Regional expression of 5-HT1B receptor mRNA in the human brain. Synapse 56: 21-8 [PMID:15700286]

459. Varnäs K, Nyberg S, Halldin C, Varrone A, Takano A, Karlsson P, Andersson J, McCarthy D, Smith M and Pierson ME et al.. (2011) Quantitative analysis of [11C]AZ10419369 binding to 5-HT1B receptors in human brain. J. Cereb. Blood Flow Metab. 31: 113-23 [PMID:20424633]

460. Vilaró MT, Cortés R, Gerald C, Branchek TA, Palacios JM and Mengod G. (1996) Localization of 5-HT4 receptor mRNA in rat brain by in situ hybridization histochemistry. Brain Res. Mol. Brain Res. 43: 356-60 [PMID:9037555]

461. Vilaró MT, Cortés R and Mengod G. (2005) Serotonin 5-HT4 receptors and their mRNAs in rat and guinea pig brain: distribution and effects of neurotoxic lesions. J. Comp. Neurol. 484: 418-39 [PMID:15770652]

462. Vilaró MT, Doménech T, Palacios JM and Mengod G. (2002) Cloning and characterization of a novel 
human $5-\mathrm{HT} 4$ receptor variant that lacks the alternatively spliced carboxy terminal exon. RT-PCR distribution in human brain and periphery of multiple 5-HT4 receptor variants. Neuropharmacology 42: 6073 [PMID:11750916]

463. Villalón CM and Centurión D. (2007) Cardiovascular responses produced by 5-hydroxytriptamine:a pharmacological update on the receptors/mechanisms involved and therapeutic implications. Naunyn Schmiedebergs Arch. Pharmacol. 376: 45-63 [PMID:17703282]

464. Voigt MM, Laurie DJ, Seeburg PH and Bach A. (1991) Molecular cloning and characterization of a rat brain cDNA encoding a 5-hydroxytryptamine1B receptor. EMBO J. 10: 4017-23 [PMID:1836757]

465. Wacker D, Wang C, Katritch V, Han GW, Huang XP, Vardy E, McCorvy JD, Jiang Y, Chu M and Siu FYet al.. (2013) Structural features for functional selectivity at serotonin receptors.Science 340: 615-9 [PMID:23519215]

466. Waeber C, Grailhe R, Yu XJ, Hen R and Moskowitz MA. (1998) Putative 5-ht5 receptors: localization in the mouse CNS and lack of effect in the inhibition of dural protein extravasation. Ann. N. Y. Acad. Sci. 861: 8590 [PMID:9928243]

467. Waeber C, Sebben M, Grossman C, Javoy-Agid F, Bockaert J and Dumuis A. (1993) [3H]-GR113808 labels 5-HT4 receptors in the human and guinea-pig brain. Neuroreport 4: 1239-42 [PMID:8219020]

468. Waeber C, Sebben M, Nieoullon A, Bockaert J and Dumuis A. (1994) Regional distribution and ontogeny of 5-HT4 binding sites in rodent brain. Neuropharmacology 33: 527-41 [PMID:7984292]

469. Wainscott DB, Cohen ML, Schenck KW, Audia JE, Nissen JS, Baez M, Kursar JD, Lucaites VL and Nelson DL. (1993) Pharmacological characteristics of the newly cloned rat 5-hydroxytryptamine2F receptor. Mol. Pharmacol. 43: 419-26 [PMID:8450835]

470. Wainscott DB, Krushinski Jr JH, Audia JE, Schaus JM, Zgombick JM, Lucaites VL and Nelson DL. (2005) [3H]LY334370, a novel radioligand for the 5-HT1F receptor. I. In vitro characterization of binding properties. Naunyn Schmiedebergs Arch. Pharmacol. 371: 169-77 [PMID:15900510]

471. Wainscott DB, Sasso DA, Kursar JD, Baez M, Lucaites VL and Nelson DL. (1998) [3H]Rauwolscine: an antagonist radioligand for the cloned human 5-hydroxytryptamine2b (5-HT2B) receptor. Naunyn Schmiedebergs Arch. Pharmacol. 357: 17-24 [PMID:9459568]

472. Wang C, Jiang Y, Ma J, Wu H, Wacker D, Katritch V, Han GW, Liu W, Huang XP and Vardy Eet al.. (2013) Structural basis for molecular recognition at serotonin receptors. Science 340: 610-4 [PMID:23519210]

473. Wang ZY, Keith IM, Beckman MJ, Brownfield MS, Vidruk EH and Bisgard GE. (2000) 5-HT5a receptors in the carotid body chemoreception pathway of rat. Neurosci. Lett. 278: 9-12 [PMID:10643788]

474. Ward SE, Harrington FP, Gordon LJ, Hopley SC, Scott CM and Watson JM. (2005) Discovery of the first potent, selective 5-hydroxytryptamine1D receptor antagonist. J. Med. Chem. 48: 3478-80 [PMID:15887956]

475. Watson J, Brough S, Coldwell MC, Gager T, Ho M, Hunter AJ, Jerman J, Middlemiss DN, Riley GJ and Brown AM. (1998) Functional effects of the muscarinic receptor agonist, xanomeline, at 5-HT1 and 5-HT2 receptors. Br. J. Pharmacol. 125: 1413-20 [PMID:9884068]

476. Watson J, Roberts C, Scott C, Kendall I, Collin L, Day NC, Harries MH, Soffin E, Davies CH and Randall AD et al.. (2001) SB-272183, a selective 5-HT(1A), 5-HT(1B) and 5-HT(1D) receptor antagonist in native tissue. Br. J. Pharmacol. 133: 797-806 [PMID:11454652]

477. Watson JM, Burton MJ, Price GW, Jones BJ and Middlemiss DN. (1996) GR127935 acts as a partial agonist at recombinant human 5-HT1D alpha and 5-HT1D beta receptors. Eur. J. Pharmacol. 314: 365-72 [PMID:8957260]

478. Watts SW, Gilbert L and Webb RC. (1995) 5-Hydroxytryptamine2B receptor mediates contraction in the mesenteric artery of mineralocorticoid hypertensive rats. Hypertension 26: 1056-9 [PMID:7498967]

479. Watts SW and Thompson JM. (2004) Characterization of the contractile 5-hydroxytryptamine receptor in the renal artery of the normotensive rat. J. Pharmacol. Exp. Ther. 309: 165-72 [PMID:14724222]

480. Weinshank RL, Zgombick JM, Macchi MJ, Branchek TA and Hartig PR. (1992) Human serotonin 1D receptor is encoded by a subfamily of two distinct genes: 5-HT1D alpha and 5-HT1D beta. Proc. Natl. 
Acad. Sci. U.S.A. 89: 3630-4 [PMID:1565658]

481. Weiss HM, Haase W, Michel H and Reiländer H. (1995) Expression of functional mouse 5-HT5A serotonin receptor in the methylotrophic yeast Pichia pastoris: pharmacological characterization and localization. FEBS Lett. 377: 451-6 [PMID:8549774]

482. Werry TD, Loiacono R, Sexton PM and Christopoulos A. (2008) RNA editing of the serotonin 5HT2C receptor and its effects on cell signalling, pharmacology and brain function. Pharmacol. Ther. 119: 7-23 [PMID:18554725]

483. Weydert A, Cloez-Tayarani I, Fillion MP, Simon-Chazottes D, Guenet JL and Fillion G. (1992) Molecular cloning of two partial serotonin 5-HT1D receptor sequences in mouse and one in guinea pig. C. R. Acad. Sci. III, Sci. Vie 314: 429-35 [PMID:1521164]

484. Whale R, Bhagwagar $Z$ and Cowen PJ. (1999) Zolmitriptan-induced growth hormone release in humans: mediation by 5-HT1D receptors? Psychopharmacology (Berl.) 145: 223-6 [PMID:10463324]

485. Wolff M, Benhassine N, Costet P, Hen R, Segu L and Buhot MC. (2003) Delay-dependent working memory impairment in young-adult and aged 5-HT1BKO mice as assessed in a radial-arm water maze. Learn. Mem. 10: 401-9 [PMID:14557613]

486. Woolley ML, Bentley JC, Sleight AJ, Marsden CA and Fone KC. (2001) A role for 5-ht6 receptors in retention of spatial learning in the Morris water maze. Neuropharmacology 41: 210-9 [PMID:11489457]

487. Wurch T, Colpaert FC and Pauwels PJ. (1998) Chimeric receptor analysis of the ketanserin binding site in the human 5-Hydroxytryptamine1D receptor: importance of the second extracellular loop and fifth transmembrane domain in antagonist binding. Mol. Pharmacol. 54: 1088-96 [PMID:9855638]

488. Xie Z, Lee SP, O'Dowd BF and George SR. (1999) Serotonin 5-HT1B and 5-HT1D receptors form homodimers when expressed alone and heterodimers when co-expressed. FEBS Lett. 456: 63-7 [PMID:10452531]

489. Xu X, Wei Y, Guo Q, Zhao S, Liu Z, Xiao T, Liu Y, Qiu Y, Hou Y and Zhang @et al.. (2018) Pharmacological Characterization of $\mathrm{H05}$, a Novel Serotonin and Noradrenaline Reuptake Inhibitor with Moderate 5- $\mathrm{HT}_{2 \mathrm{~A}}$ Antagonist Activity for the Treatment of Depression.J. Pharmacol. Exp. Ther. 365: 624635 [PMID:29615471]

490. Xu YC, Schaus JM, Walker C, Krushinski J, Adham N, Zgombick JM, Liang SX, Kohlman DT and Audia JE. (1999) N-Methyl-5-tert-butyltryptamine: A novel, highly potent 5-HT1D receptor agonist. J. Med. Chem. 42: 526-31 [PMID:9986723]

491. Yang W, Chen K, Lan NC, Gallaher TK and Shih JC. (1992) Gene structure and expression of the mouse 5-HT2 receptor. J. Neurosci. Res. 33: 196-204 [PMID:1333538]

492. Yoshioka M, Matsumoto M, Togashi H, Mori K and Saito H. (1998) Central distribution and function of 5HT6 receptor subtype in the rat brain. Life Sci. 62: 1473-7 [PMID:9585121]

493. Yu L, Nguyen H, Le H, Bloem LJ, Kozak CA, Hoffman BJ, Snutch TP, Lester HA, Davidson N and Lübbert H. (1991) The mouse 5-HT1C receptor contains eight hydrophobic domains and is X-linked. Brain Res. Mol. Brain Res. 11: 143-9 [PMID:1661811]

494. Zgombick JM and Branchek TA. (1998) Native 5-HT1B receptors expressed in OK cells display dual coupling to elevation of intracellular calcium concentrations and inhibition of adenylate cyclase. Naunyn Schmiedebergs Arch. Pharmacol. 358: 503-8 [PMID:9840417]

495. Zgombick JM, Schechter LE, Macchi M, Hartig PR, Branchek TA and Weinshank RL. (1992) Human gene S31 encodes the pharmacologically defined serotonin 5-hydroxytryptamine1E receptor. Mol. Pharmacol. 42: 180-5 [PMID:1513320]

496. Zhang JY, Nawoschik S, Kowal D, Smith D, Spangler T, Ochalski R, Schechter L and Dunlop J. (2003) Characterization of the $5-\mathrm{HT} 6$ receptor coupled to $\mathrm{Ca} 2+$ signaling using an enabling chimeric G-protein. Eur. J. Pharmacol. 472: 33-8 [PMID:12860470] 